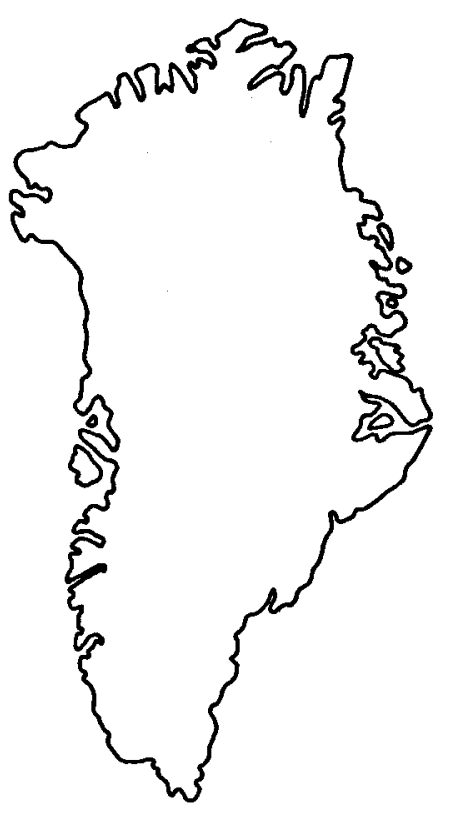

Spirellus and related helically coiled microfossils (cyanobacteria) from the Lower Cambrian of North Greenland

\author{
John S. Peel
}

Phosphatised helically coiled microfossils are described from the Portfjeld Formation of Early Cambrian age in southern Peary Land, central North Greenland. Spirellus Jiang in Luo et $a l ., 1982$, originally described from the Meishucunian Stage of China, is recorded from Greenland and interpreted as a filamentous cyanobacterium showing variable degrees of mineralisation of the sheath. Jiangispirellus groenlandicus gen. et sp. nov. is described, based on helically coiled naked trichomes with preserved cell structure. Both genera are compared to Obruchevella Reitlinger, 1948 which is also reported from Greenland for the first time.

J. S. P., Grønlands Geologiske Undersøgelse, Øster Voldgade 10, DK-1350 København K, Danmark.

Microscopic, helically coiled tubes have been known from thin-sections of strata adjacent to the Precambrian-Cambrian boundary in the Soviet Union for four decades (Reitlinger, 1948). A number of taxa are described in the literature, notably by Reitlinger $(1948,1959)$ and Vologdin (1958), of which the best known is probably the genus Obruchevella Reitlinger, 1948 (see summary by Loeblich \& Tappan, 1964). Obruchevella has subsequently been reported from other areas of the world, for example, the Middle East and Alaska (Cloud et al., 1979) and strata near the Precambrian-Cambrian boundary in China (Song in Luo et al., 1984; Song, 1984; Zhang, 1984; Awramik et al., 1985). Shenfil' (1980) reported a species of Riphean age from the Soviet Union while specimens of Devonian age, also from the Soviet Union, have been reported by Chuvashov et al. (1985).

Obruchevella was originally assigned to the Foraminifera by Reitlinger (1948), an opinion apparently supported by Vologdin (1958). Reitlinger (1959) subsequently considered this position to be uncertain and later suggested that either a foraminiferal or algal assignment was possible (Reitlinger, 1960, cited after Cloud et al., 1979). In the Treatise on Invertebrate Paleontology, Obruchevella and the rest of the similar, mainly Lower Cambrian fossils were included in an Order Reitlingerellida by Loeblich \& Tappan (1964). The Reitlingerellida, as such, was proposed to accomodate a number of problematic fossils which at various times in their history have been considered to be Foraminifera. Several coiled genera of Ordovician 
age whose relationship is tenuous were also included (Bykova, 1961, see also Schallreuter, 1977).

In later years, it has become widely accepted that Obruchevella is a cyanobacterium (cyanophyte) of the Family Oscillatoriaceae similar in form to the Recent Spirulina (Luchinina, 1975; Voronova, 1976; Cloud et al., 1979; Pyatiletov et al., 1981; Luchinina \& Voronova, 1983; Song, 1984; see also Riding \& Voronova, 1984, 1985).

In contrast to most specimens of Obruchevella, specimens referred to the genus Spirellus Jiang in Luo et al., 1982 (referred to as both Spirellus and Spirella by Luo et al., 1984) are phosphatic microfossils etched from carbonates by the use of weak acids. The type species, $S$. columnaris, and one other species were originally described from the latest Precambrian and earliest Cambrian Meishucunian Stage of eastern Yunnan by Jiang in Luo et al. (1982; see also Luo et al., 1984), but Spirellus is also described from the Cambrian of the Himalayas (Azmi, 1983; Bhatt et al., 1983; Bhatt et al., 1985; Kumar et al., 1987; Brasier \& Singh, 1987) where the Glomerula shankari of Singh \& Shukla (1981) is probably a senior synonym of $S$. columnaris. Brasier (1984) has reported a possible specimen from the Cambrian of the English Midlands.

Jiang referred Spirellus to the animalian Order Hyolithelminthes Fischer, 1962 and this assignment was also accepted by Azmi (1983). Brasier (1984) considered its affinities to be problematic, as did Bhatt et al. (1985), while Brasier \& Singh (1987) tentatively considered Spirellus to be a skeletal alga.

In the present paper, helically coiled tube-like microfossils are described from Lower Cambrian dolomites of the Portfjeld Formation in southern Peary Land, central North Greenland (figs 1-3). A preliminary report of their occurrence was given by Peel (1980). Individual fossils are phosphatised and have been etched from the parent carbonate using dilute acetic acid. The material permits evaluation of the relationship between Spirellus and Obruchevella and provides additional information concerning the nature of these problematic forms from the vicinity of the Precambrian-Cambrian boundary.

It is concluded that Spirellus and a new genus with preserved cell structure described as Jiangispirellus are cyanobacteria related to Obruchevella.

\section{Derivation of material}

All specimens described in this paper were obtained by processing dolomite of GGU sample 271769 in weak acetic acid. Rare and poorly preserved specimens occur in a second sample (GGU 271764) treated in the same manner. Both samples were collected by Peter Frykman and myself in 1978 from a measured section through the Portfjeld Formation, west of the two lakes $\emptyset$ vre Midsommers $\emptyset$ and Nedre Midsommers $\emptyset$ (unofficially referred to as 'Midsommersøer'), southern Peary Land (figs 1-3). A number of other dolomite samples from this and other sections through the Portfjeld Formation in Peary Land and adjacent areas of central North Greenland have been processed using the same techniques, but without yielding microfossils.

The Portfjeld Formation was first described by Jepsen (1971) with a type locality designated just east of 'Midsommersøer', some $30 \mathrm{~km}$ east of the section described in fig. 3 . According to O'Connor (1979), the formation varies in thickness from $200 \mathrm{~m}$ to $280 \mathrm{~m}$ in southern Peary Land, where it is composed typically of pale weathering, planar or irregular laminated to thin bedded dolomites, commonly with small-scale (ripple) cross-bedding. 


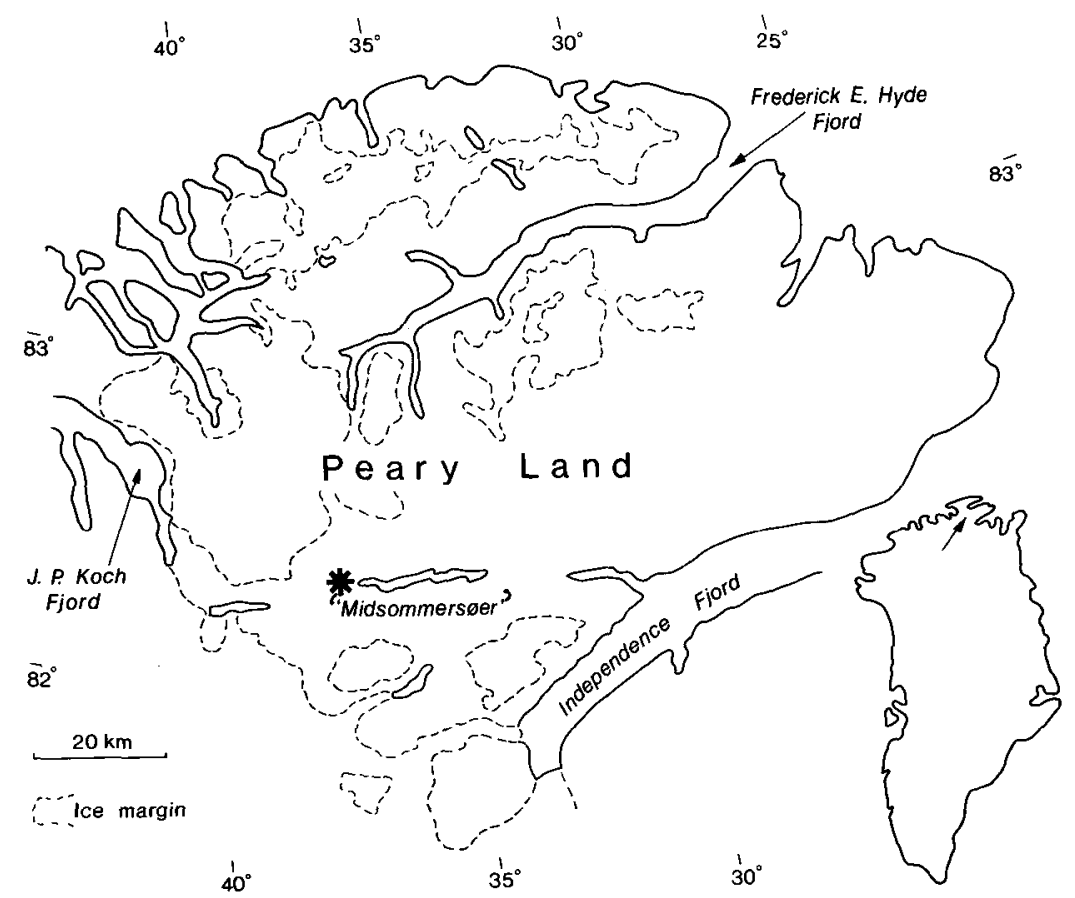

Fig. 1. The Peary land region of central North Greenland showing the collection locality for fossil cyanobacteria described in this paper (star).

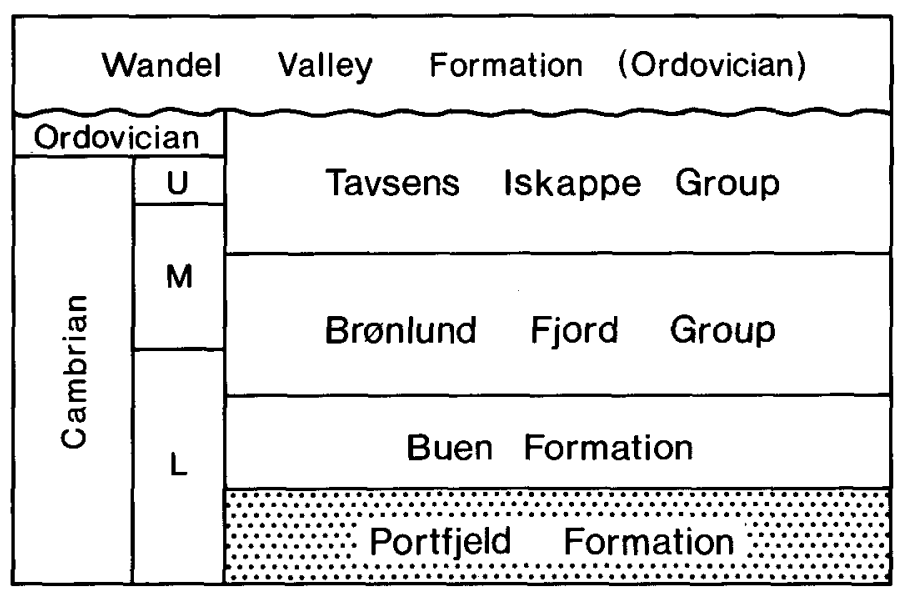

Fig. 2. Stratigraphy of Cambrian shelf sequences in southern Peary Land. All described specimens are from the Portfjeld Formation of Early Cambrian age. In the area around the collection locality, the Portfjeld Formation overlies the Morænes $\varnothing$ Formation which lies in hollows within the Inuiteq S $\varnothing$ Formation (both Proterozoic, see Jepsen, 1971). In more northern localities in North Greenland, the Portfjeld Formation overlies presumed Cambrian strata assigned to the Skagen Group (Higgins et al., in press; Surlyk \& Ineson, 1987; see discussion in text). 
Units of cross-bedded oolitic or intraclastic dolomite, intraformational flat-pebble conglomerate and various forms of stromatolitic dolomite also occur, as do subordinate medium to coarse grained sandstones. A persistent unit of dolomite breccia with a dolomite matrix rich in quartz sand grains, may reflect a palaeokarstic event. As noted by Jepsen (1971) and O'Connor (1979), a unit of dark grey, bituminous dolomite rich in bedded and nodular chert, forms a conspicuous mapping horizon throughout the region. It is from the base of this unit that the fossiliferous dolomite sample GGU 271769 was collected. Pedersen (1970; 1976) recorded thread-like and globular microfossils in chert from the same horizon. GGU sample 271764 was collected from cross-bedded, oolitic dolomite near the base of the formation (fig. 3).

The Portfjeld Formation of southern Peary Land was deposited in shallow subtidal and intertidal environments on a marine carbonate platform (O'Connor, 1979; Higgins et al., in press). Palaeokarstic breccias with grains of well-rounded quartz and intervals of mature, medium to coarse grained sandstones probably indicate periodic emergence. The formation thickens to the north in Peary Land and becomes dominated by grainstones as the platform margin is approached. Beyond the platform margin, to the north of the Frederick E. Hyde Fjord area (fig. 1), the Paradisfjeld Group forms a deep-water trough equivalent to the Portfjeld Formation (Friderichsen et al., 1982; Peel, 1982; Hurst \& Surlyk, 1983; Higgins et al., in press).

\section{Age of the Portfjeld Formation}

In GGU sample 271769 Jiangispirellus, Spirellus and Obruchevella occur together with smooth phosphatised spheres resembling Olivooides Qian, 1977. The spheres are 200-300 $\mu \mathrm{m}$ in diameter and often wrinkled or crumpled. Similar spheres occur in late Lower Cambrian strata elsewhere in North Greenland (J. S. Peel, unpublished observation). Olivooides occurs together with Spirellus at Meishucun and in the Indian Himalaya (Luo et al., 1984; Brasier \& Singh, 1987).

Spirellus columnaris and Obruchevella parva were described from unit 5 of the Zhongyicun Member of the Yuhucun Formation at Meishucun, China (Luo et al., 1984; Song, 1984). Although assigned to the Meishucunian Stage, this unit lies below the candidate horizon ('China B' of Luo et al., 1984) for the Precambrian-Cambrian boundary which is placed a few metres higher in the section at the base of unit 7 of the Zhongyicun Member (Luo et al., 1984; Cowie, 1985).

In India, S. shankari occurs in the Chert-Phosphorite Member of the Lower Tal Formation. Brasier \& Singh (1987), in describing this occurrence, drew parallels between the Chert-Phosphorite Member and beds 4-5 of the Zhongyicun Member at Meishucun.

Obruchevella and related forms have been quite widely studied from Precambrian (Riphean) to early Cambrian deposits but their distribution in younger strata is less well charted. Chuvashov et al. (1985) document a Devonian occurrence. Thus, in the absence of more age-diagnostic faunal elements, no suggestion is made that the Portfjeld Formation of Greenland is of Meishucunian age (latest Precambrian - earliest Cambrian), even though this would be in accord with the earlier suggestion of Pedersen $(1970,1976)$.

In the area of the measured section at 'Midsommersøer' (fig. 1), the Portfjeld Formation overlies the Morænes $\emptyset$ and Inuiteq Sø Formations of Proterozoic age. In more northerly areas of North Greenland, the Portfjeld Formation overlies a mainly siliciclastic sequence 

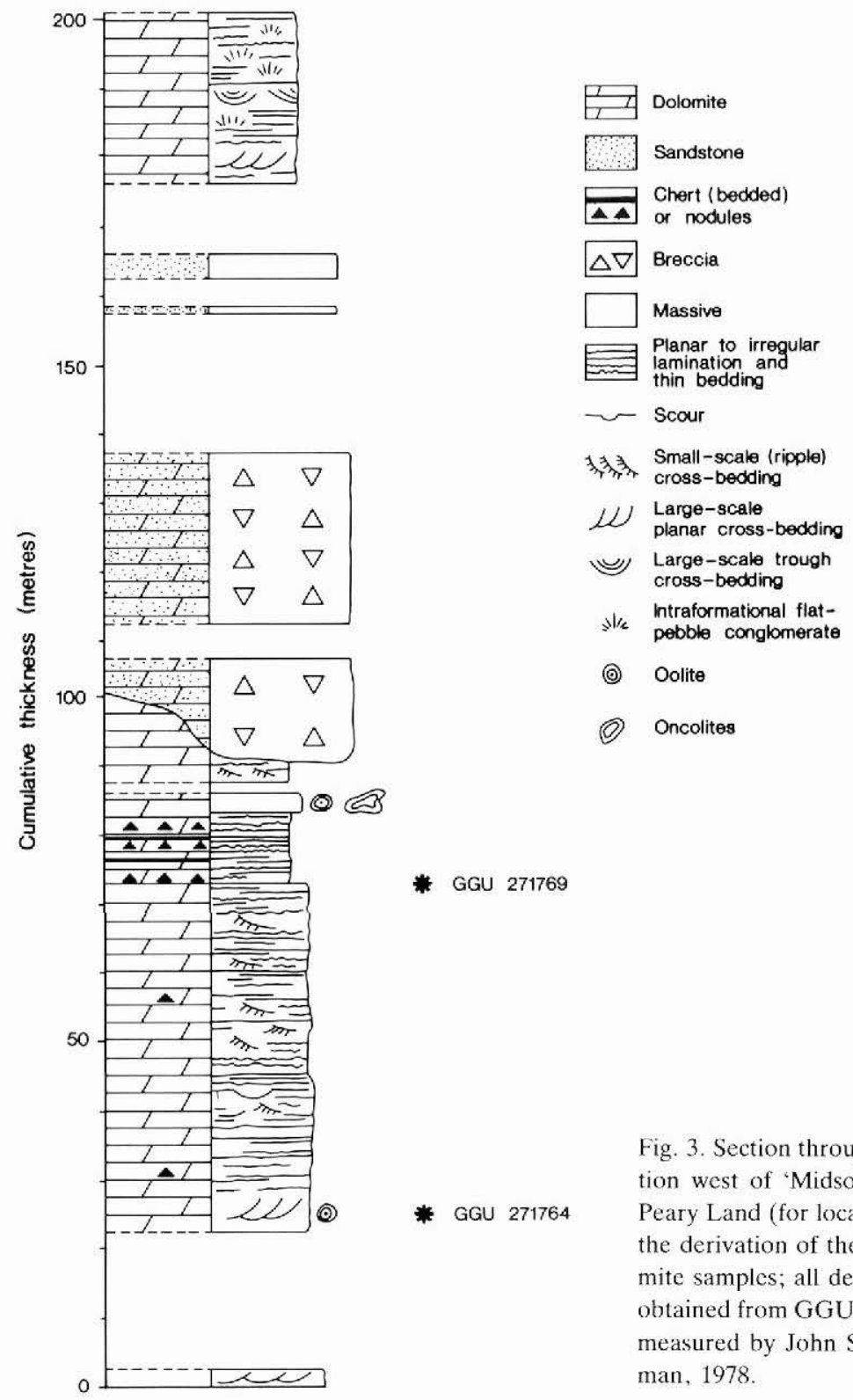

Fig. 3. Section through the Portfjeld Formation west of 'Midsommersøer' in southern Peary Land (for location see fig. 1) showing the derivation of the two fossiliferous dolomite samples; all described specimens were obtained from GGU sample 271769. Section measured by John S. Peel and Peter Frykman, 1978.

referred to the Skagen Group (Surlyk \& Ineson, 1987; Higgins et al., in press). This unit has not yielded fossils but can be correlated on regional and lithological grounds with the Kennedy Channel Formation of Judge Daly Peninsula, eastern Ellesmere Island, Canada (Dawes \& Peel, 1984) which has yielded an undescribed fauna of Early Cambrian age, including Chancelloria, Pelagiella and fragments of trilobites and brachiopods. Palmer \& 
Peel (1979; see also Peel, 1982; Conway Morris et al., 1987; Blaker, 1988) have recorded ?middle to late Early Cambrian faunas from the Buen Formation which conformably overlies the Portfjeld Formation in North Greenland. In conjunction with the fauna from Judge Daly Peninsula, the Buen fauna suggests that a similar ?middle to late Early Cambrian age can be assigned to the Portfjeld Formation.

\section{Nature of the helical thread}

The most simple thread-like form within present day cyanobacteria consists of a long, single row of cells termed a trichome which may vary from approximately straight to spirally coiled. The trichome (or an intermingled bundle of trichomes) secretes a mucilaginous layer which, to a greater or lesser extent, covers the row of cells. This mucilaginous layer may vary from a thin, barely discernible coating to the trichome, to a robust and relatively firm sheath. The combination of a trichome and a sheath is termed a filament.

Mineralisation in Recent cyanobacteria is mainly characteristic of freshwater forms although marine mineralised cyanobacteria were conspicuous from the Early Cambrian to the Cretaceous (Pentecost \& Riding, 1986). Carbonate precipitation occurs by impregnation of the mucilaginous sheath of living cyanobacteria or by encrustation of filaments (Pentecost \& Riding, 1986). Mineralised sheaths are the commonly preserved form of filamentous cyanobacteria in Lower Palaeozoic and later rocks (Flügel, 1977; Wray, 1977; Riding \& Voronova, 1985; Pentecost \& Riding, 1986). Calcareous deposition on filaments may also occur at the present day during early cementation, an early diagenetic effect (Schroeder, 1972). All three forms of mineralisation may occur within the fossil record and subsequent diagenetic changes, such as the phosphatisation described here in the specimens from North Greenland, may effectively obscure the origin of fossil mineralised envelopes.

Specimens from the Portfjeld Formation assigned to the new taxon Jiangispirellus groenlandicus, described below, are preserved as phosphatised helices (figs 6-9). Most examined specimens display well preserved cell structure on the outer surface of the thread while the inner surface lacks annulation (fig. 6B). This might suggest that the helices as preserved are phosphatic casts of external moulds of trichomes and that continued deposition of phosphate has to a greater or lesser extent filled the cavity left by degradation of the organic thread. Less frequently, traces of annulation are visible on the inner surface of the helical tube indicating that intercellular walls were at least partly intact at the time of formation of the phosphate and that phosphate was deposited on the inner surface of the cell wall. Phosphatised cross-partitions have not been observed within the tubes, however, suggesting that while phosphate formation commenced within partly intact cells, it probably continued after the internal structure of the trichomes was lost.

Thus, the annulation in $J$. groenlandicus could result from internal moulding of individual cells (at least initially) or from casting of a mould of the trichome exterior. If the former process took place, the annulation can give no reliable indication of the presence or absence of a sheath in the original thread and $J$. groenlandicus may well have possessed a sheath surrounding its row of cells. In contrast, if casting was the dominant process, it is likely that no sheath was present, unless phosphatisation took place on the inner surface of a more resistant sheath after loss of the trichome. The presence of external moulds of helices carrying the impression of the annulation (fig. 9C) supports the dominance of casting of a 
naked trichome in the fossilisation of Jiangispirellus, since such external moulds would not be produced if a mineralised sheath was present.

Some material assigned to Spirellus shankari (Singh \& Shukla, 1981) also appears to represent fossilised threads without mineralised envelopes (figs 10-12). No evidence of cell structure is visible either in the threads or on external moulds of the threads. Thus, a relatively substantial sheath probably covered the presumed trichome, and the thread in Spirellus should be considered to be a filament.

\section{Preserved cell structure in Jiangispirellus}

Structures within the tube of Obruchevella apparently were first reported by Pyatiletov $e$ al. (1981) who noted cross-partitions interpreted as cell walls in specimens from the Riphean of the Soviet Union. Song (1984; see also Luo et al., 1984) described similar specimens from the Meishucunian of China. Song speculated that the hollow tube in his specimens of Obruchevella without mineralised envelopes could be formed by loss of the internal cell walls (cross-partitions), leaving the outer cell wall of the trichome to define the tube. Alternatively, he proposed that degradation of the entire trichome within a filament left the sheath to form the wall of the hollow tube.

As noted above, the annulated threads described here as Jiangispirellus groenlandicus are interpreted as a representation of cell structure. Individual cells within the trichome are discoid with their length (measured along the trichome) being only about one sixth of their width. The sides of each cell are very slightly convex or flat, but narrow constrictions or grooves on the trichome mark the position of each intercellular wall.

Supposed cell structure is well known in many Precambrian and younger fossil cyanobacteria. Forms such as Oscillatoriopsis and Palaeolyngbya among the many Precambrian taxa described by Schopf (1968) and Schopf \& Blacic (1971) display closely similar trichome structure to that seen in Jiangispirellus, although known from thin sections of cherts rather than isolated phosphate replicas.

Further support for this interpretation of Jiangispirellus is gained from a study by Demoulin \& Janssen (1981) of the relationship between cell shape and filament width in recent cyanobacteria. They noted that cell shape in surveyed living forms changed from cylindrical (defined as cell length more than twice cell width) to discoid (cell width more than twice cell length) as the width of the filament increased. Demoulin \& Janssen speculated that the trend reflected the short life of Messenger RNA within the procaryote cells of cyanobacteria by keeping the distance between the nucleoplasm and the cell periphery to a minimum. In their own samples from Corsica, Demoulin \& Janssen (1981) found that 80 filaments out of a total of 5,618 measured filaments had widths greater than $10 \mu \mathrm{m}$ and in all these filaments the cells were discoid in form. Nine per cent of cells in 2,588 filaments between $2 \mu \mathrm{m}$ and $10 \mu \mathrm{m}$ in diameter were discoid $(85.5 \%$ were equidimensional and $5.5 \%$ cylindrical), while only $1 \%$ of cells were discoid in 2,951 filaments less than $2 \mu \mathrm{m}$ in diameter (58\% equidimensional, $41 \%$ cylindrical).

Demoulin \& Janssen (1981) extended their survey to standard treatises (e.g. Fremy, 1933 and Desikachary, 1959) noting that the discoid cell form dominated in filaments greater than $5-10 \mu \mathrm{m}$ in diameter. They also referred to a filamentous cyanobacterium from the Red Sea in which cells within the up to $100 \mu \mathrm{m}$ wide filaments varied in size from $48-80 \mu \mathrm{m}$ in width and 3-8 $\mu \mathrm{m}$ in length, a width:length ratio ranging from 7.5 to 25.8 . Trichomes of Jiangispi- 
rellus groenlandicus from the Portfjeld Formation are made up of cells about $50 \mu \mathrm{m}$ in width, with a length of about one sixth of this amount (figs 6-9). These values are comparable to those noted by Demoulin \& Janssen in the living form from the Red Sea which should dispell some of the concern expressed by Brasier \& Singh (1987) concerning the oscillatoriacean affinity of Spirellus.

Song (1984, Table 2) recorded original cell structure in Obruchevella, where individual cells (length 2.5-3 $\mu \mathrm{m}$ ) occurring in the much narrower threads (width 3-10 $\mu \mathrm{m}$ ) were relatively larger than in $J$. groenlandicus. The dimensions given by Song are also broadly comparable with those of Demoulin \& Janssen (1981).

Natural terminations of the trichome in Jiangispirellus groenlandicus are not known. However, in two specimens assigned to Spirellus shankari, the filament is seen to terminate abruptly in a uniformly convex surface apparently representing the terminal cell. In one specimen (figs $11 \mathrm{~A}, 12$ ) the filament is wrinkled and considered to be un-mineralised; in the second specimen (figs 14A, 15) a thick mineralised sheath is inferred.

\section{Mineralisation and morphogenera}

Early descriptions of Obruchevella indicated a parallel-sided hollow tube coiled into an approximately uniform helix. According to Riding \& Voronova (1984, p. 206), the tube wall in the type material of Obruchevella is calcareous, although the wall has been silicified in other specimens from the Yudomian (late Precambrian) Tinov Formation reported by Reitlinger (1959, p. 21). In original illustrations of the type species, Obruchevella delicata, presented by Reitlinger (1948, pl. 1, figs 1, 2), the calcareous wall of the tube is relatively thick, varying in thickness from about one third of the diameter of the internal cavity, to equally as thick as the diameter of the cavity itself. The calcareous wall is dark in the figures and clearly delimited from the surrounded paler matrix. In the lower part of both of the specimens figured by Reitlinger, carbonate of the calcareous wall appears to fill the central cavity of the helix.

Song (1984) assigned to Obruchevella specimens from chert horizons within the Zhongyicun Member of the Yuhucun Formation (Meishucunian Stage) of Yunnan, China, which

Fig. 4A. Scattergram showing the relationship between the width of the thread and the external diameter of the helix in Late Precambrian and Early Cambrian cyanobacteria. An Obruchevella field, based on measurements given by Song (1984) with crosses indicating the variation in size of the various species, is clearly distinguished from fields occupied by Greenland specimens of Spirellus shankari (open stars) and Jiangispirellus groenlandicus (filled stars). The heavily mineralised specimen of Spirellus shankari (MGUH 17.584, fig. 14A) is shown at its present dimensions (AA) and with the width of the thread reduced to $40 \mu \mathrm{m}$ by stripping of the mineral sheath (AB) to show the effects of progressive mineralisation. Filled circle, Obruchevella cf. $O$. parva, MGUH 17.570. Filled square, Spirellus columnaris, the specimen figured by Jiang in Luo et al. (1982, pl. 15, fig. 1, the holotype); open square, same, specimen figured as pl. 15, fig. 2.

Fig. 4B. As fig. 4A but extended to include heavily mineralised specimens of Spirellus from the Lower Tal Formation. The lines BA-BB and CA-CB delimit a field showing the effects of progressive mineralisation on the sample of Spirellus shankari from Greenland. Specimens of $S$. columnaris (filled triangles) and $S$. tarsus (open triangle) sensu Azmi (1983) lie within this field; specimens of $S$. shankari measured from Singh \& Shukla (1981) are indicated by open circles mainly beyond the field. 

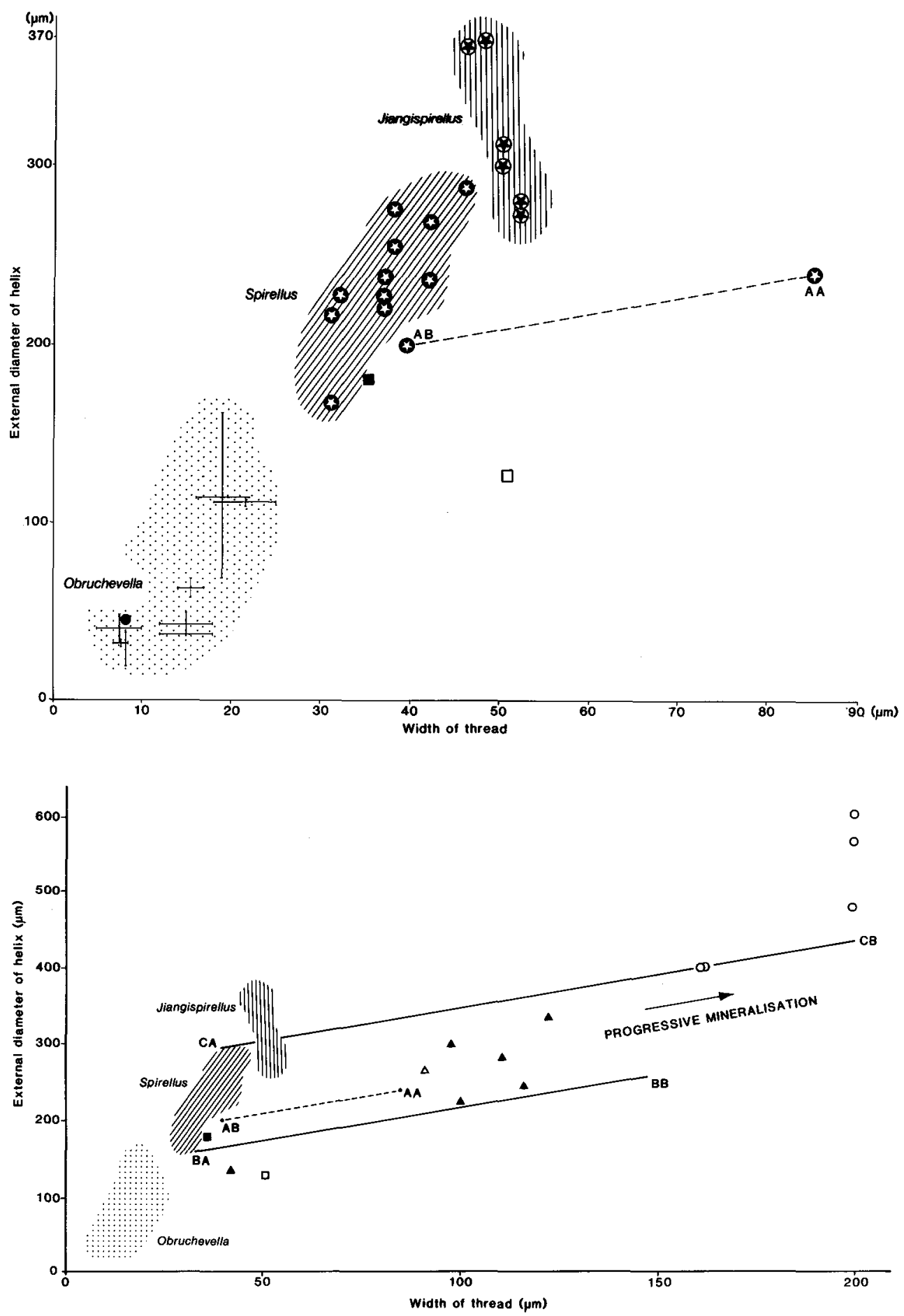
lack the thick mineralised envelope preserved in the type suite from the Soviet Union. His illustrated material is from thin-sections of cherts which clearly show thin-walled tubes and there is no reason to presume that mineralisation was developed during life.

Song (1984, p. 183) concluded that Obruchevella is a morphogenus formed by spirally coiled trichomes or filaments. Following his usage, which is similar to that of Pyatiletov et al. (1981), Obruchevella includes forms both with and without mineralised envelopes. However, the detailed structure of the thread remains unknown in virtually all specimens and species. Thus, the spiral tube of Obruchevella may be expected to have been produced by a variety of different cyanobacteria, or possibly even by other organisms.

The specimen from the Portfjeld Formation here assigned to Obruchevella preserves a thick envelope surrounding the inner cavity, but this envelope is now phosphatised (fig. 5). Neither the original composition of this wall, nor the nature of the thread it is presumed to have contained, are known.

Conclusions similar to those reached by Song (1984) concerning the morphogeneric nature of other Lower Palaeozoic cyanobacteria have been made by several authors, for example Riding (1977) and Pratt (1984), see also Riding \& Voronova (1984, 1985). Spirellus is here treated in the same fashion. As with Obruchevella, in the sense of Song (1984), Spirellus may include forms with originally un-mineralised sheaths and also forms in which the sheath was heavily mineralised; the mineral envelope in the latter could conceal various kinds of threads. The nature of the thread is not known in species previously assigned to Spirellus. However, in specimens of $S$. shankari, described below, the thread is considered to be a filament (figs 10-15).

The degree of mineralisation of the filament can clearly influence the systematics of fossil cyanobacteria without necessarily having any real systematic significance. In reviewing calcification in cyanobacteria, Pentecost \& Riding (1986) noted that while some Recent freshwater forms show specificity for calcification, none appear to be obligate calcifers. Specificity, however, decreases as marine influence increases.

Increased mineralisation produces specimens which are many times larger than the enclosed cyanobacterial threads. The result of this is clearly seen in Spirellus shankari from the Portfjeld Formation where presumed un-mineralised filaments are associated with less common, heavily mineralised examples (figs $14 \mathrm{~A}, 15$ ). The heavily mineralised specimen (AA in fig. 4A) is readily united with others of the species by progressive removal of the mineralised envelope (AB). Fig. 4B demonstrates that very large specimens from India described by Azmi (1983) as Spirellus columnaris and $S$. tarsus probably can be considered conspecific with the North Greenland specimens referred to $S$. shankari (see later for further discussion). It is naturally recognised that possible differences may exist in filament structure within the mineralised envelope between these forms but that these are obscured by the method of preservation.

The uniform width of the mineralised filament and its smooth surface suggests that mineralisation in Greenland Spirellus (figs 14A, 15) resulted from impregnation of the sheath rather than encrustation. Thus, the variation in thickness of the mineralised envelope between Greenland and Indian material may reflect variation in the thicknes of the sheath or in the location of mineralisation within the sheath. The sheath in Recent forms is known to vary in thickness and structure and sheath development can be environmentally controlled (Pentecost \& Riding, 1986). 
While a broad morphogeneric approach is possibly the only one available in most geological settings, it is not followed exclusively in the present context on account of the exceptional preservation of some of the available specimens from the Portfjeld Formation. The new genus Jiangispirellus is described to accomodate well preserved specimens which differ in the structure of the helically coiled thread forms assigned to Spirellus. It is acknowledged that material assigned here to Jiangispirellus might be placed within Spirellus under less favourable conditions of preservation. It is also stressed that the assignment of any material to Spirellus is arbitrary since the structure of the type material is not known.

Spirellus is maintained as a genus distinct from Obruchevella on account of its greater dimensions, both in terms of the width of the filament and the diameter of the helix (fig. 4A). Species assigned to the latter genus form a compact group near the origin in fig. $4 \mathrm{~A}$. Spirellus is located more distally; increased mineralisation of the sheath displaces the scatter toward the right of the plot.

\section{Degradational variation}

The possibility that helices referred to Jiangispirellus groenlandicus and Spirellus shankari may be degradational variants of the same form has been considered, but is rejected. If specimens of Spirellus lost the sheath it is possible that individual cells of the trichome would be visible, as in $J$. groenlandicus, but these degraded forms would be expected to be narrower than the original Spirellus. It is evident from fig. 4A that the opposite relationship is the case, and that the trichomes of $J$. groenlandicus tend to be slightly wider than filaments (sheath + trichome) of $S$. shankari without mineralised sheaths. Trichomes of $J$. groenlandicus are obviously narrower in terms of width of the thread than strongly mineralised specimens of $S$. shankari.

\section{SYSTEMATIC PALAEONTOLOGY}

Deposition of material. All type and figured specimens (MGUH prefix) are deposited in the type collection of the Geological Museum, Copenhagen. Additional material (GGU prefix) is preserved by the Geological Survey of Greenland, Copenhagen.

It should be noted that MGUH 17.576, illustrated here in figs $10 \mathrm{~A}, 11 \mathrm{~A}$ and 12 , was damaged subsequent to photography such that the coil was broken into 4 fragments, one of which was lost. The specimen illustrated as fig. 10B was destroyed at the same time and has consequently not been assigned a type (MGUH) number.

\section{Genus Obruchevella Reitlinger, 1948}

Type species. Obruchevella delicata Reitlinger, 1948.

Discussion. Lukaschevella Vologdin, 1958 closely resembles specimens of Obruchevella which lack a mineralised envelope in terms of size and style of coiling and may be a junior synonym. Volyniella Aseeva, 1976 also resembles un-mineralised Obruchevella in general appearance and size but this organic-walled form was interpreted by Tynni \& Donner (1980, fig. 2) as a cylindrical stack of large individual cell rings rather than a tightly coiled helical thread. 


\section{Obruchevella cf. O. parva Reitlinger, 1959}

Fig. 5

Illustrated specimen. MGUH 17.570 from GGU sample 271769, Portfjeld Formation, southern Peary Land.

Description. This single small specimen contains traces of ten coils, but the parallel-sided helix is broken at both ends. The external diameter of the helix is approximately $50 \mu \mathrm{m}$, measured on the outside of the phosphatised envelope and 40-45 $\mu \mathrm{m}$ when measured internally. The cylindrical thread itself is about $8 \mu \mathrm{m}$ wide, measured inside the phosphatised envelope, and of uniform width; the specimen thus lies well within the Obruchevella field in fig. 4. No trace of the thread itself is preserved, and its structure is thus unknown. The phosphatised envelope surrounding the supposed thread is of relatively uniform thickness and may be a replacement of an original calcareous sheath; a central cavity is present within the helix.

Discussion. The single Greenland specimen lies within, but at the periphery of, the scattergram plot of a sample of specimens of Obruchevella parva illustrated by Song (1984, fig. 2) from the Zhongyicun Member of the Yuhucun Formation (Meishucunian) of Yunnan Province, China. The specimen is somewhat larger than $O$. parva from the Yudomian Tolbinsk Formation of Siberia, according to measurements given by Song (1984, Table 3)

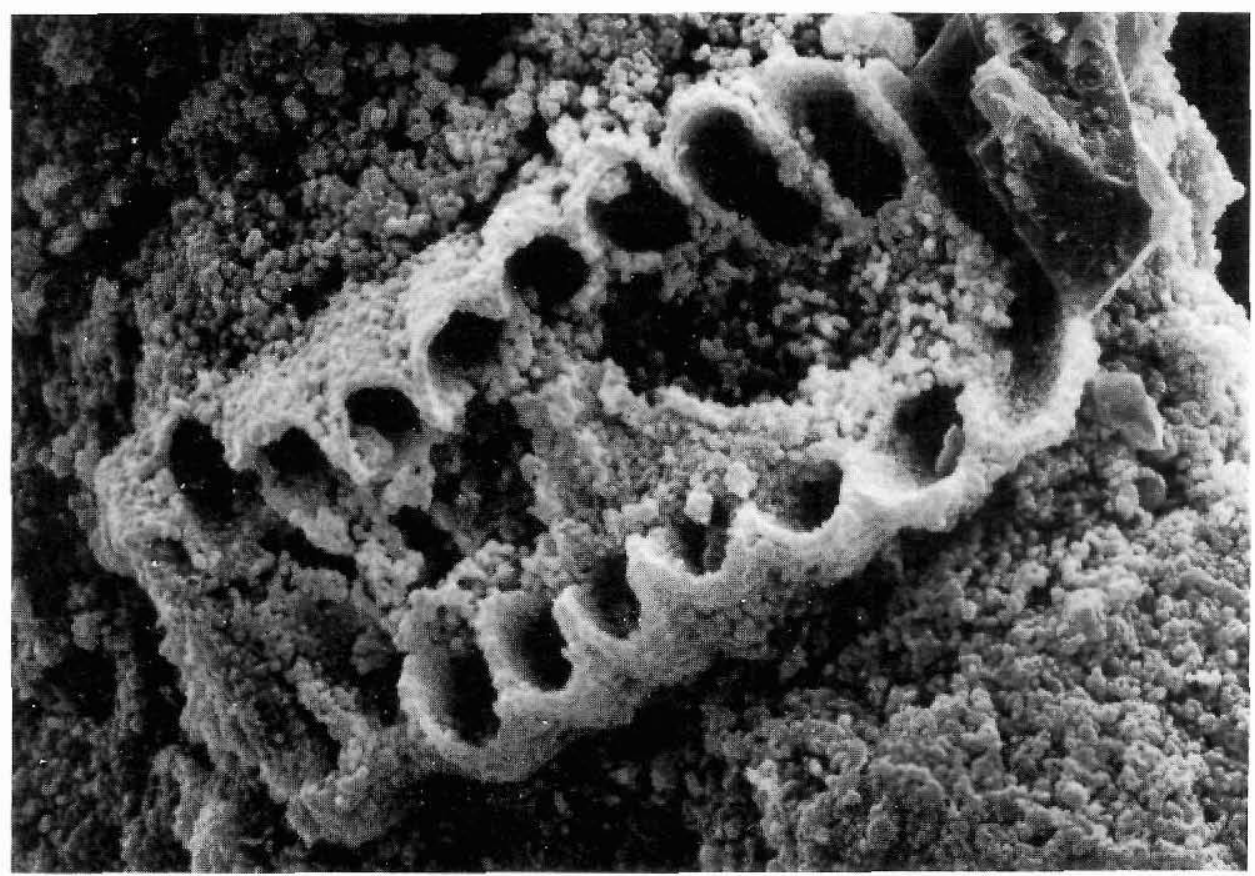

Fig. 5. Obruchevella cf. O. parva Reitlinger, 1959. MGUH 17.570 from GGU sample 271769, Portfjeld Formation, southern Peary Land, $\times 1000$. 
which give Reitlinger's species a helix diameter of 30-34 $\mu \mathrm{m}$ and a filament width of 6.8-8.5 $\mu \mathrm{m}$. Song also presents similar dimensions for material illustrated by Cloud et al. (1979) from the supposed late Precambrian Jubaylah Group of Saudi Arabia.

Obruchevella cf. $O$. parva from Greenland differs from $O$. delicata Reitlinger, 1948 from the Lower Cambrian of Siberia in having a narrower filament. Song (1984, Table 3; see also Zhang, 1984, Table 1) gives dimensions of 12-18 $\mu \mathrm{m}$ for the filament of the latter specimens, based on records by Reitlinger (1959), Luchinina (1975) and Yakschin \& Luchinina (1981). The width of the helix of the Siberian $O$. delicata is given as $36-49 \mu \mathrm{m}$, which is comparable to the Greenland specimen. A specimen from the Meishucunian of China ascribed to $O$. delicata by Song (1984, Table 3 ) lies at the lower end of the size range of the Siberian examples, in terms of width of the helix.

Dimensions of other species of Obruchevella presented by Song (1984, Table 3) generally indicate forms with a wider filament than $O$. cf. $O$. parva and a broader helix (O. sibirica Reitlinger, 1959; O. ditissima Yakschin \& Luchinina, 1981; O. meishucunensis Song, 1984). In one species, however, the Meishucunian form $O$. parvissima Song, 1984, the filament (3-4 $\mu \mathrm{m})$ and the helix $(20-24 \mu \mathrm{m})$ are much narrower.

Obruchevella blandita Shenfil', 1980 from the Riphean of Siberia differs from $O$. cf. $O$. parva in being a much smaller species. Shenfil' (1980) noted a helix diameter of 18-20 $\mu \mathrm{m}$ and a thread only $2.1-2.2 \mu \mathrm{m}$ in width in this, the oldest known species of Obruchevella. A new species described by Zhang (1984) as $O$. minor, from the Toushantou Formation (= Doushantuo Formation, Late Precambrian) of Hubei, China, is also considerably smaller than the Portfjeld Formation specimen of $O$. cf. $O$. parva. Zhang noted an average helical width of $13.5 \mu \mathrm{m}$ and filaments in the range $3-5.5 \mu \mathrm{m}$.

Song (1984, p. 181) noted Obruchevella spp. from the Zhongyicun Member with threads $32 \mu \mathrm{m}$ wide and helices with diameters up to $645 \mu \mathrm{m}$. These dimensions suggest the Spirellus of Jiang in Luo et al. (1982) which is not referred to directly in Song's paper.

\section{Genus Jiangispirellus gen. nov.}

Type species. Jiangispirellus groenlandicus gen. et sp. nov.

Derivation of name. For Jiang Zhiwen, who described the closely related genus Spirellus.

Diagnosis. Helically coiled microfossils in which a circular thread, interpreted as a trichome, with an approximate width of $50 \mu \mathrm{m}$ is coiled into a parallel-sided helix varying in diameter from about $270-370 \mu \mathrm{m}$. Individual whorls may be in contact, or the helix may be open coiled; the central cavity of the helix is open. Coiling may be dextral or sinistral. Surface of the thread annulated with individual segments interpreted as cells. Width of the individual cells in the type species, measured transverse to the thread, is approximately eight times greater than their length.

Discussion. Jiangispirellus can be closely compared to Spirellus in terms of the general dimensions of the thread and the helix (fig. 4A). However, most specimens assigned to Spirellus by Azmi (1983) are larger than Jiangispirellus and the original material of Spirellus from China (see fig. 4 and discussion elsewhere). Both Spirellus and Jiangispirellus are 


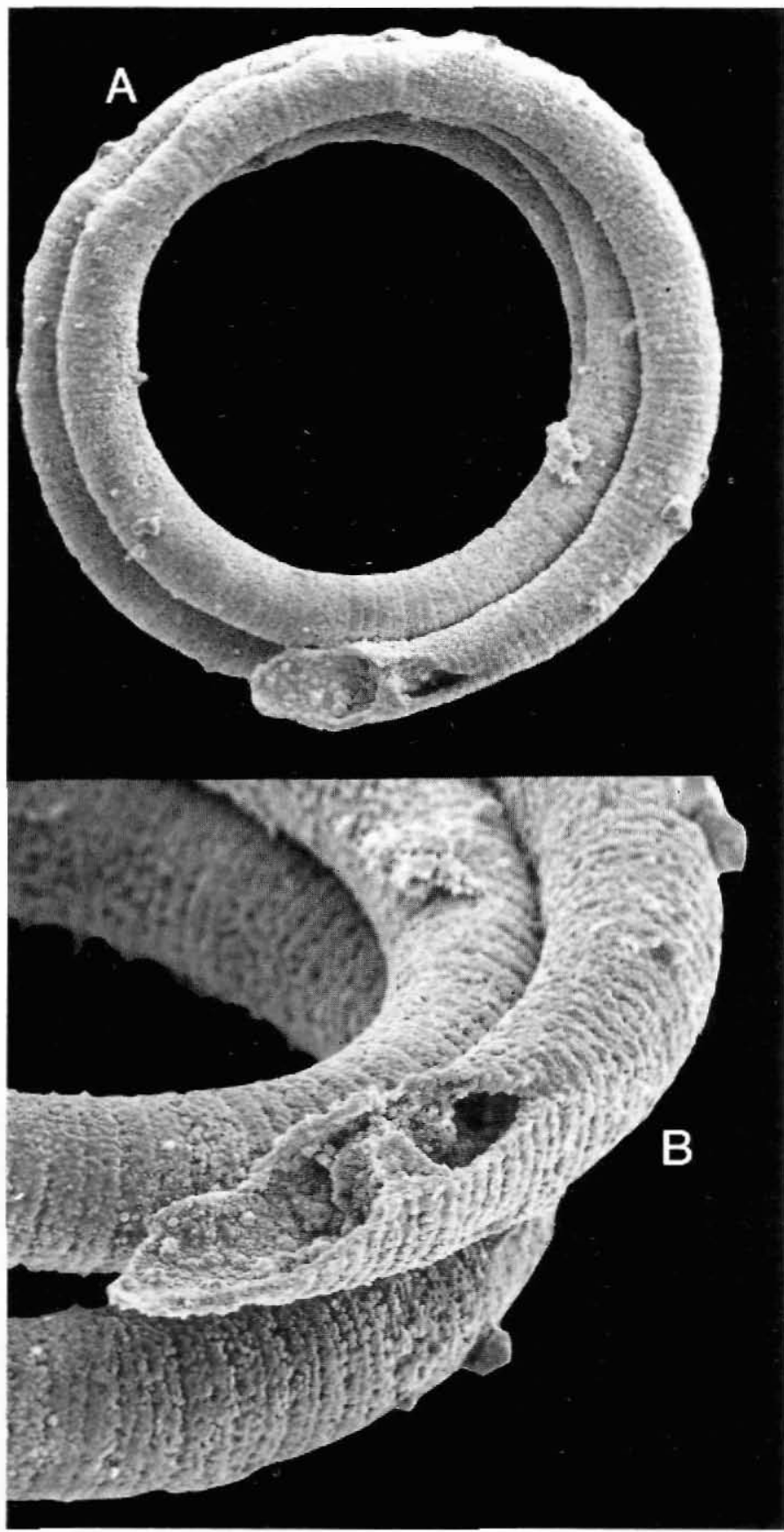

Fig. 6. Jiangispirellus groenlandicus gen. et sp. nov., holotype, MGUH 17.571 from GGU sample 271769, Portfjeld Formation. A, axial view showing cell structure in the helically coiled trichome. $\times 200$. B, detail of the phosphatised tube showing external cell structure and coarse, granular inner surface, $\times 450$. 
significantly larger than the various species occupying the Obruchevella field in the same figure.

Jiangispirellus differs from Spirellus in being a naked trichome without a preserved sheath and, consequently, without a mineralised envelope. Material from Greenland here referred to Spirellus shankari is known from both originally un-mineralised and mineralised filaments. Pyatiletov et al. (1981) and Song (1984) have recorded original cell structure in Obruchevella. Individual cells in specimens listed by Song (1984, Table 2) in the much narrower threads $(3-10 \mu \mathrm{m})$ are proportionally much larger (length $2.5-3 \mu \mathrm{m}$ ) than in Jiangispirellus.

Jiangispirellus groenlandicus sp. nov.

Figs 6-9

Holotype. MGUH 17.571 from GGU sample 271769, Portfjeld Formation, southern Peary Land.

Additional illustrated material. MGUH 17.572-17.575, all from the same sample as the holotype.

Other material. Common in GGU sample 271769.

Description. Type and only known species of Jiangispirellus gen. nov., the diagnosis of which is given above. The natural terminations of the helically formed trichome are not known since all available material is broken. Annulation in the phosphate replicas from the Portfjeld Formation takes the form of closely spaced narrow constrictions (interpreted as representing individual cell walls) which delimit segments (considered to reflect the individual cells) with shallowly convex walls. In the holotype, as illustrated in fig. 8, the individual cylindrical cells thus attain a width of about $50 \mu \mathrm{m}$ (the width of the trichome) and a length of $8 \mu \mathrm{m}$. Specimens of $J$. groenlandicus have the whorls of the helix in contact (figs 7,9A) or the helix may be open-coiled (fig. 9B); in both cases, the circular cross-section of the trichome is usually maintained. A lack of parallelism of the sides of the helix in some fragments, e.g. the holotype (figs 6, 7), indicates some degree of shortening of the helix. However, the maintenance of the general circular plan of the helix and the circular crosssection of the trichomes demonstrate that this is most probably a pre-burial phenomenon

Fig. 7. Jiangispirellus groenlandicus gen. et sp. nov., holotype, MGUH 17.571 from GGU sample 271769, Portfjeld Formation. Stereo-pair, $\times 100$.

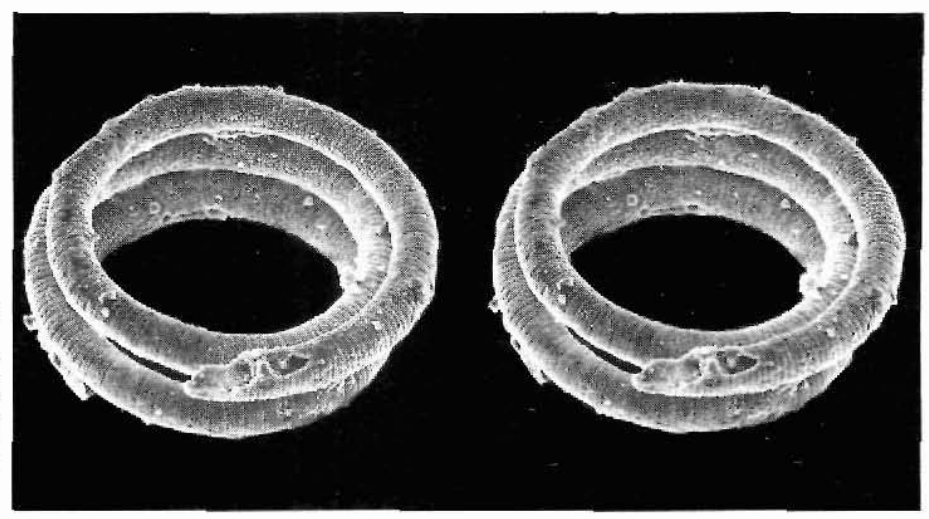




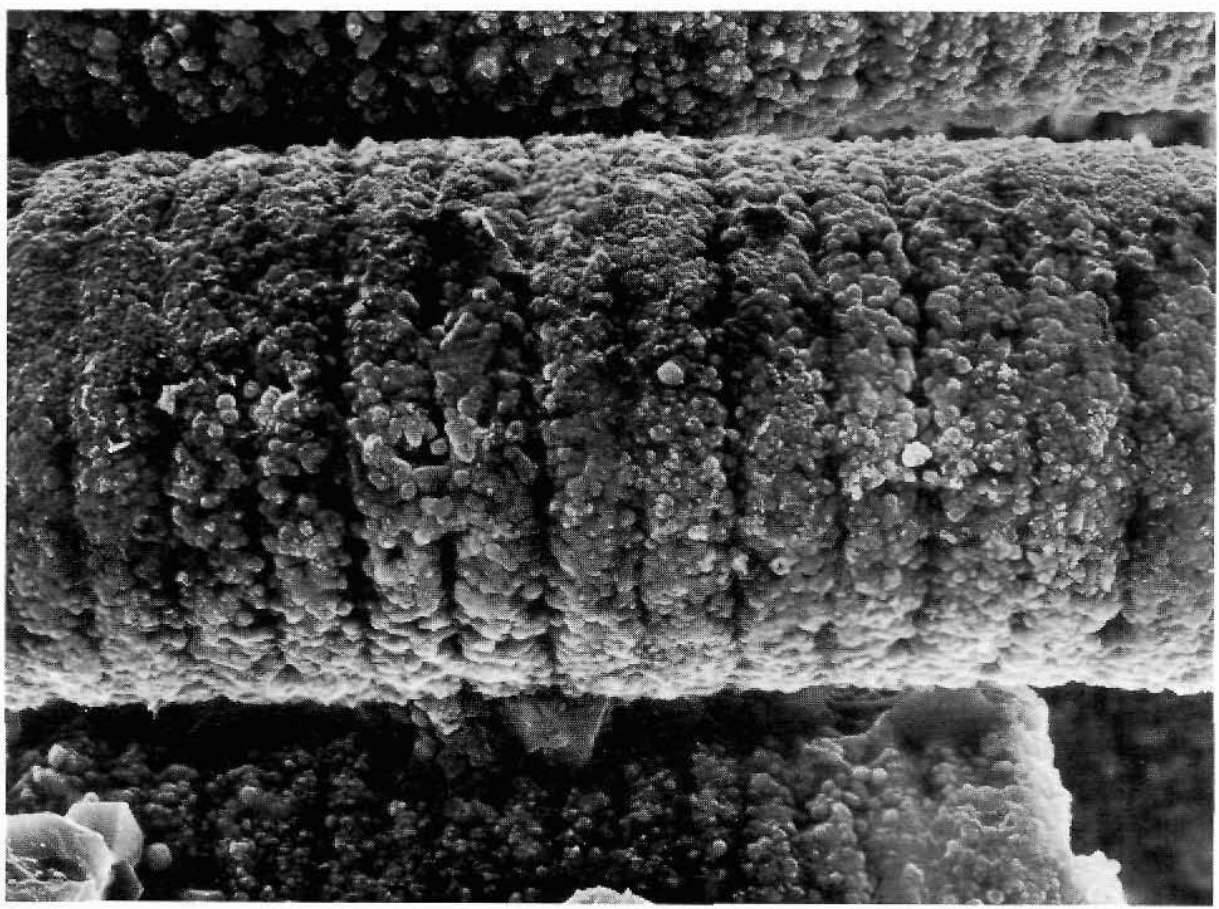

Fig. 8. Jiangispirellus groenlandicus gen. et sp. nov., holotype, MGUH 17.571 from GGU sample 271769 , Portfjeld Formation. Detail of phosphatised trichome showing cell structure, $\times 1,100$.

rather than sedimentary diagenesis. Moulds composed of the sediment filling the hollow centre of the individual helices are quite common in the available acid residues of the phosphatised sample from Peary Land (figs 9C, 13). Some of these bear the impression of cell structure and can therefore be assigned to J. groenlandicus (fig. 9C).

Discussion. The principal difference between Jiangispirellus groenlandicus and associated specimens of Spirellus shankari in which the filament lacks a mineral envelope is the presence of the well-developed annulation in the former, discussed above. Threads of Jiangispirellus are thus interpreted as trichomes while those of $S$. shankari are considered to be filaments. Specimens of $J$. groenlandicus tend to be slightly wider than these accompanying specimens of $S$. shankari both in terms of width of the thread and the diameter of the helix. This indicates that $J$. groenlandicus is not a degraded form of Spirellus in which the outer sheath has been stripped away, since such degradation would produce the opposite relationship in terms of measured dimensions.

Specimens of Spirellus shankari in the same sample with heavily mineralised sheaths are readily distinguished from $J$. groenlandicus by their mineral envelope (now phosphatised, but probably originally calcareous) and resultant greater diameter of the thread. 


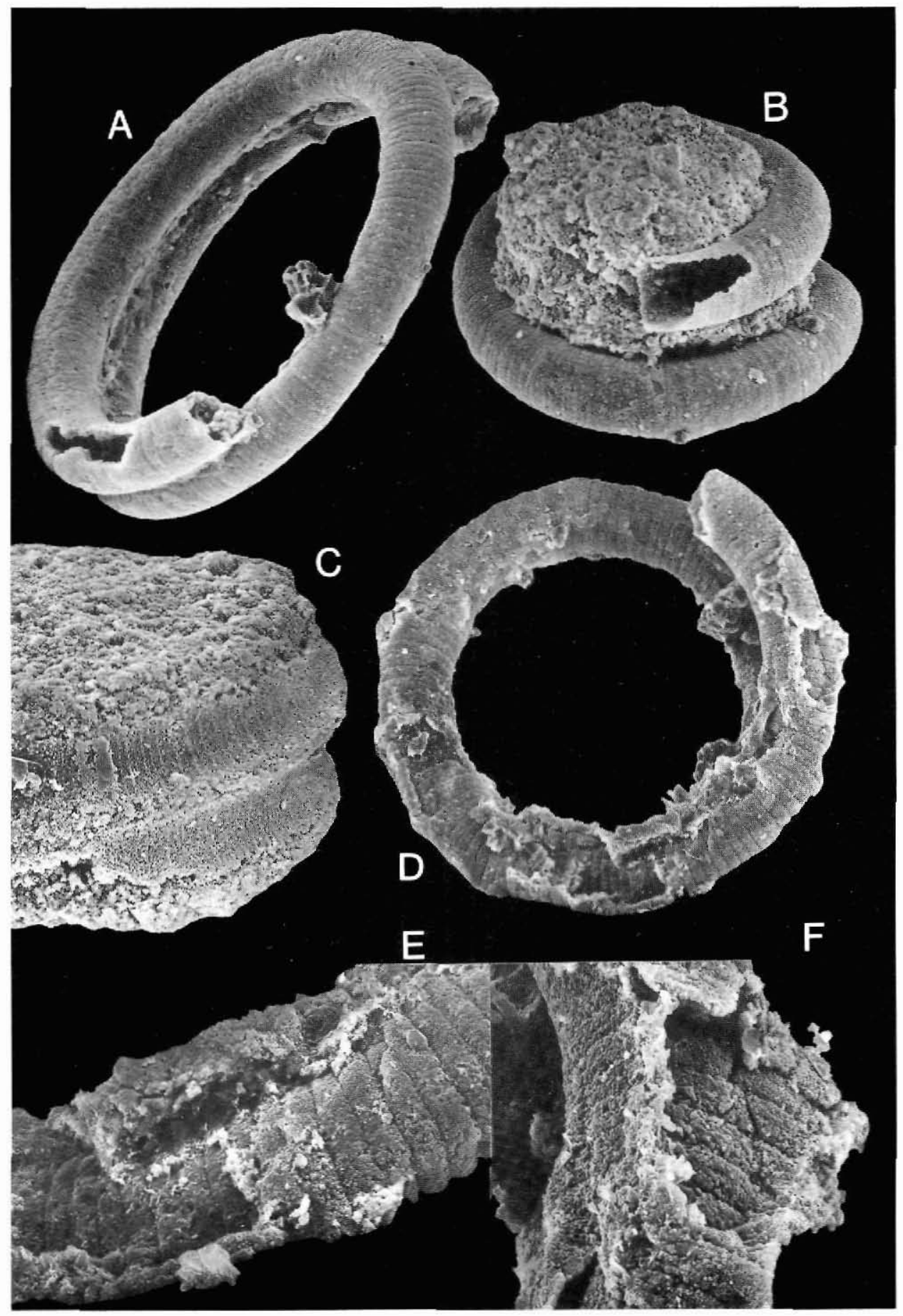

Fig. 9. Jiangispirellus groenlandicus gen. et sp. nov. All specimens from GGU sample 271769, Portfjeld Formation. A, MGUH 17.572, $\times 200$. B, MGUH 17.573, a slightly open coiled example, $\times 200$. C, MGUH 17.574, external mould of the trichome from the inner cavity of the helix showing impression of cell structure, $\times 270$. D-F, MGUH 17.575 in axial view and showing details of cell structure in the partly crushed, phosphatised trichome, $\times 200$ and $\times 600$. 
Genus Spirellus Jiang in Luo et al., 1982

1982 Spirellus Jiang in Luo et al., 1982.

1984 Spirella Jiang in Luo et al., 1984.

Type species. Spirellus columnaris Jiang in Luo et al., 1982.

Diagnosis (emended). Helically coiled microfossils in which the thread may be essentially un-mineralised or enveloped in a heavily mineralised envelope; both forms are currently preserved in phosphate in available material. The helix commonly has a diameter of at least $150 \mu \mathrm{m}$, the thread diameter is greater than about $30 \mu \mathrm{m}$, but both dimensions may be considerably greater due to progressive mineralisation. The thread is parallel-sided and smooth, without annulation; its natural termination is smooth and uniformly convex.

Discussion. Spirellus is considered to be a cyanobacterium in which the helically coiled thread is interpreted as a filament. The sheath may be mineralised or not; the nature of the trichome within this presumed sheath is not known.

Spirellus is closely comparable to Obruchevella from which it can be distinguished by its greater dimensions. In Obruchevella the helix is seldom wider than $100 \mu \mathrm{m}$ and the thread and envelope are most commonly less than $20 \mu \mathrm{m}$ (figs 4, 5). Spirellus is distinguished from Jiangispirellus by the presence in the latter genus of a single, naked trichome, without an enclosing sheath.

The spelling variant Spirella was used consistently by Luo et al. (1984). Similarly, the type species has been referred to variously as $S$. columnarus, $S$. cilumnarus and $S$. columnorus in Luo et al. (1982, pp. 173, 237 and 254) and as $S$. columnorus in Luo et al. (1984). Brasier $(1984$, p. 240$)$ cited $S$. columnaris as the type species and this corrected spelling is used here.

Jiang (in Luo et al., 1982) made no reference to Glomerula shankari Singh \& Shukla, 1981 in describing Spirellus columnaris. Differences in preservation and dimensions between the forms from China and India can be explained in terms of the degree of mineralisation of the sheath which is essentially un-mineralised in the Chinese specimens and heavily mineralised in the Indian material. The two species are united, in agreement with Brasier \& Singh (1987), and S. columnaris Jiang in Luo et al., 1982) from China is thus considered to be a junior subjective synonym of $S$. shankari, described a year earlier from the Indian Himalaya.

\section{Spirellus shankari (Singh \& Shukla, 1981)}

Figs 10-15

1981 Glomerula shankari Singh \& Shukla, p. 163, pl. 1, figs 1-31, pl. 2, fig. 78.

1982 Spirellus columnarus Jiang in Luo et al., p. 173, fig. 49, pl. 15, figs 1, 2.

Spirellus cilumnarus Jiang in Luo et al., p. 237.

Spirellus columnorus Jiang in Luo et al., p. 254.

1984 Spirella columnorus; Jiang in Luo et al., pl. 10, figs 14, 15.

1987 Spirellus shankari ; Brasier \& Singh, pp. 341-342, figs 8.14-8.18 (includes full synonymy).

Illustrated material. MGUH 17.576-17.584, from GGU sample 271769, Portfjeld Formation, southern Peary Land.

Other material. Common in the GGU sample 271769. 


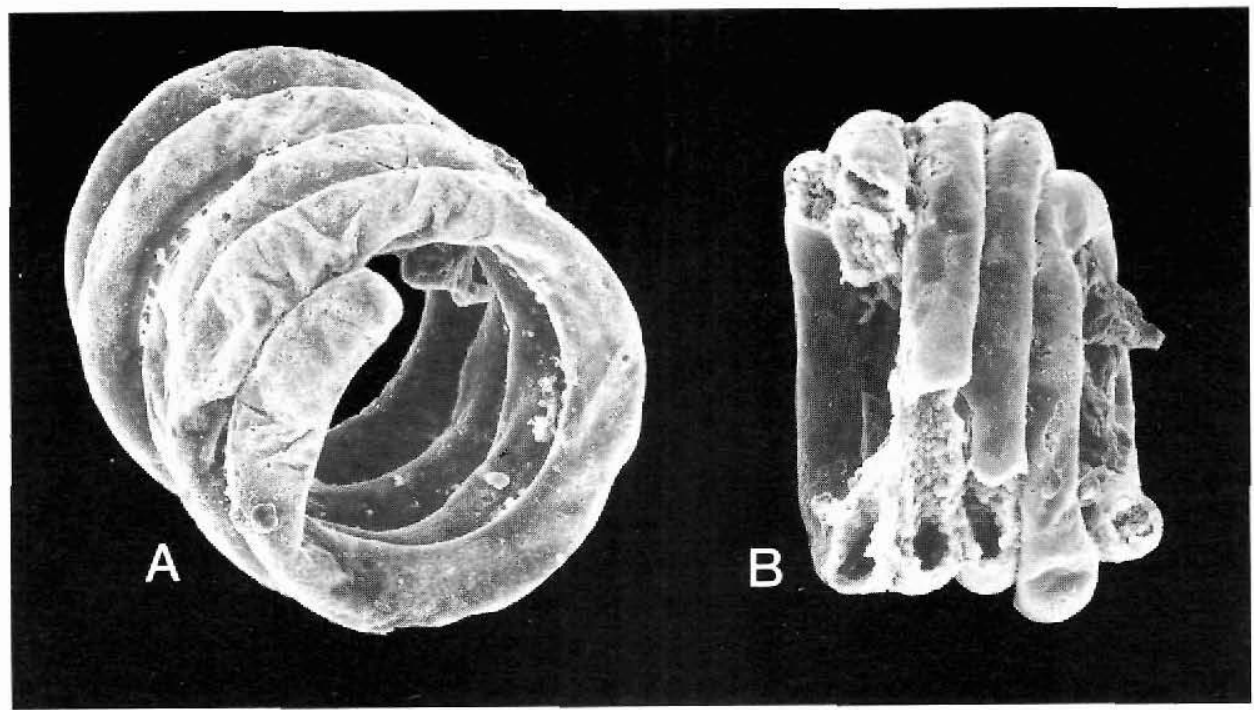

Fig. 10. Spirellus shankari (Singh \& Shukla, 1981), phosphatised filaments in which the slightly irregular, non-parallel sides of the helix may indicate compression or collapse ('slippage') along the axis of coiling, bringing adjacent whorls into contact, GGU sample 271769, Portfjeld Formation, $\times 200$. A, MGUH 17.576, note the rounded termination of the filament (see also figs 11A, 12). Subsequent to photography, this specimen was damaged. The helix was crushed and broken into four fragments; the fragment carrying the rounded termination to the filament was lost. B, un-numbered specimen, lost subsequent to photography.

Description. Species of Spirellus Jiang in Luo et al., 1982 in which a cyanobacterial thread interpreted as a single filament is variably enclosed within a mineral envelope, interpreted as a mineralised sheath; the envelope is preserved as phosphate but its original composition was probably calcareous. Coiling is apparently normally sinistral in Greenland specimens but Chinese specimens of the type species are sinistral or dextral.

Three different preservational forms occur within material placed here. In the first of these (fig. 11B), the parallel-sided helix has a diameter of about $200 \mu \mathrm{m}$ and the filament is almost $40 \mu \mathrm{m}$ in width. Individual whorls of the helix are not in contact and maintain a uniformly circular cross-section. A core of phosphatised sediment lies within the helix in the illustrated specimen, giving the entire specimen the impression of being a solid rod with a ridge spirally disposed on its surface. Sediment moulds of the inside of the helix of other specimens indicate that the whorls may have been more closely juxtaposed, or even in contact (fig. 13). This preservational variant is interpreted as a pristine filament; the similarity of its dimensions with the second preservational form, described below, suggests that the filament was naked or that any mineralisation of the sheath was minimal.

Individual whorls within the helix in the second preservational form are almost always in contact with preceding and succeeding whorls. The sides of the helix show a poor degree of parallelism (figs 10,12) and general form clearly gives the impression of an helix which has undergone shortening (and hence deformation) along its axis of coiling ('slippage'). The surface of the filament is smooth, as in the first preservational variant. The imperfect circular 


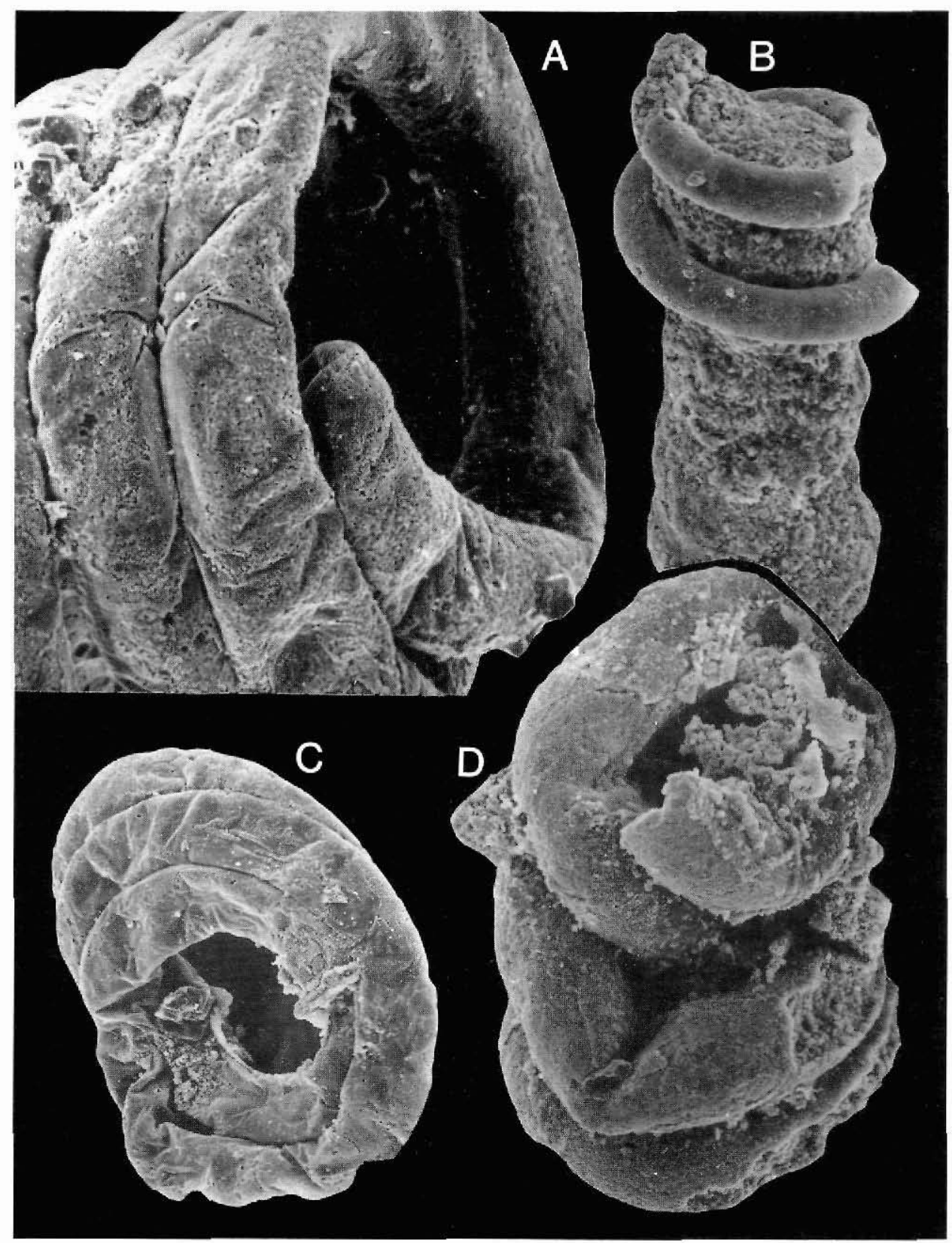

Fig. 11. Spirellus shankari (Singh \& Shukla, 1981), phosphatised filaments showing variation in preservation, GGU sample 271769 , Portfjeld Formation. A, MGUH 17.576 showing the wrinkled and etched surface and the rounded termination of the filament, $\times 450$, see also figs 10A, 12. B, MGUH 17.577, open coiled, pristine specimen with uniformly rounded filament; the good preservation may reflect slight mineralisation of the sheath, $\times 200$. C, MGUH 17.578, the wrinkled surface of the degraded filament suggests no mineralisation of the sheath, $\times 200$. D, MGUH 17.579, the thickness and angular bending of the coiled filament suggest that this specimen possesses a relatively strongly mineralised sheath similar to that seen in fig. $14 \mathrm{~A}, \times 200$. 
Fig. 12. Spirellus shankari (Singh \& Shukla, 1981). MGUH 17.576 from GGU sample 271769 , Portfjeld Formation. Stereo pair, showing the rounded termination of the filament, $\times 100$; see also figs $10 \mathrm{~A}, 11 \mathrm{~A}$.

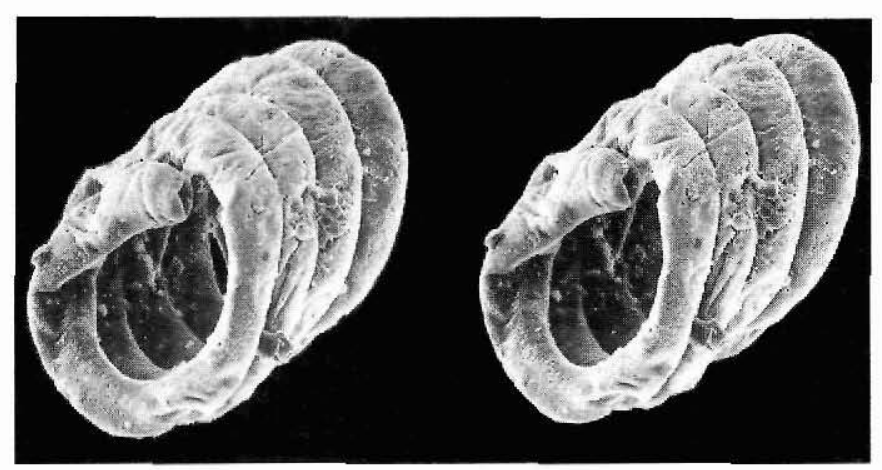

cross-section and wrinkled surface visible in figs $10,11 \mathrm{~A}, 11 \mathrm{C}$, suggest that this second preservational variant is merely a degraded form of the first (fig. 11B); the wrinkling suggests that the sheath lacked mineralisation. In specimens which have suffered a higher degree of degradation the helical form is proportionally less perfect and the cross-sectional profile less circular (fig. 11C). Specimens of the degraded variant show a range in diameter of the helix from about $170 \mu \mathrm{m}$ to about $290 \mu \mathrm{m}$; the width of the filament in the same sample varies between $30 \mu \mathrm{m}$ and $48 \mu \mathrm{m}$ (fig. $4 \mathrm{~A}$ ). One of the illustrated specimens (figs 10A, 11A, 12) shows the abruptly rounded termination of the filament.

The thread is relatively much thicker in the third preservational variant due to substantial

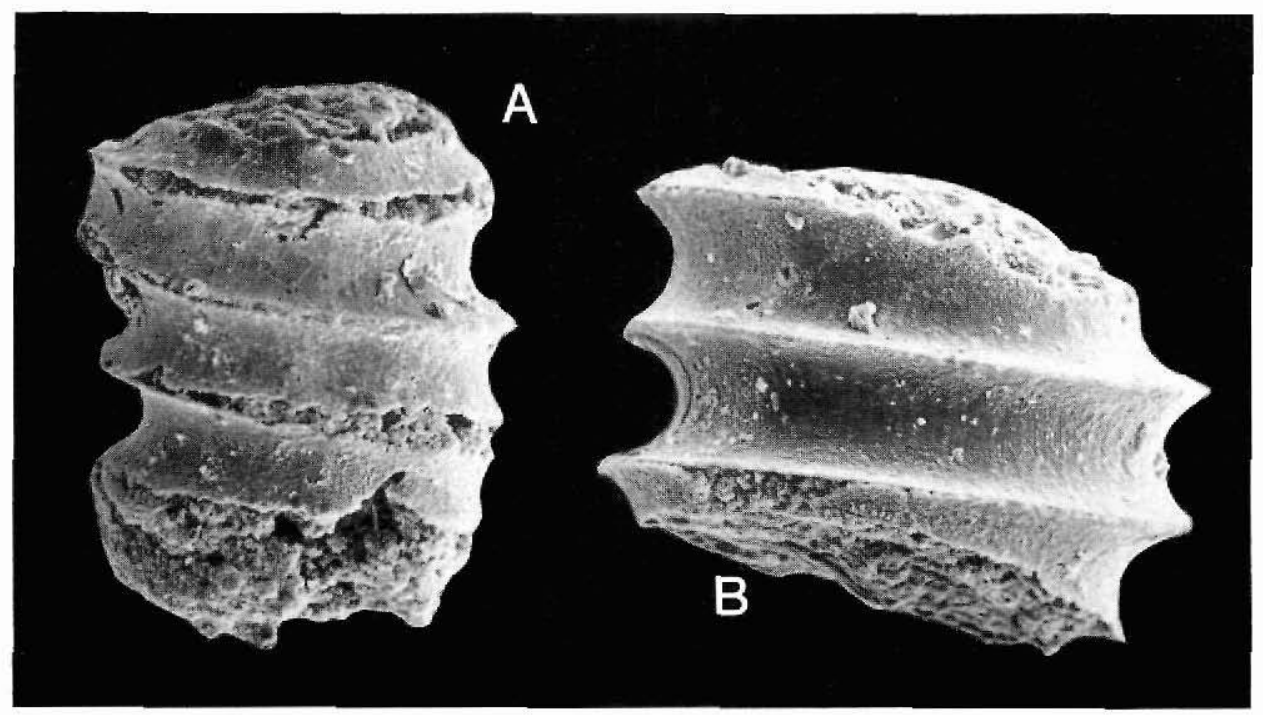

Fig. 13. Spirellus shankari (Singh \& Shukla, 1981). GGU sample 271769, Portfjeld Formation. External moulds of the filament representing the sediment-filled centre of the helix, cf. fig. 11B. A, MGUH 17.580, the broken crests between the impressions of successive coils indicate that the coils of the filament were not perfectly in contact, $\times 200$. B, MGUH 17.581, sharp crests indicate that successive coils of the filament were in contact, $\times 300$. 


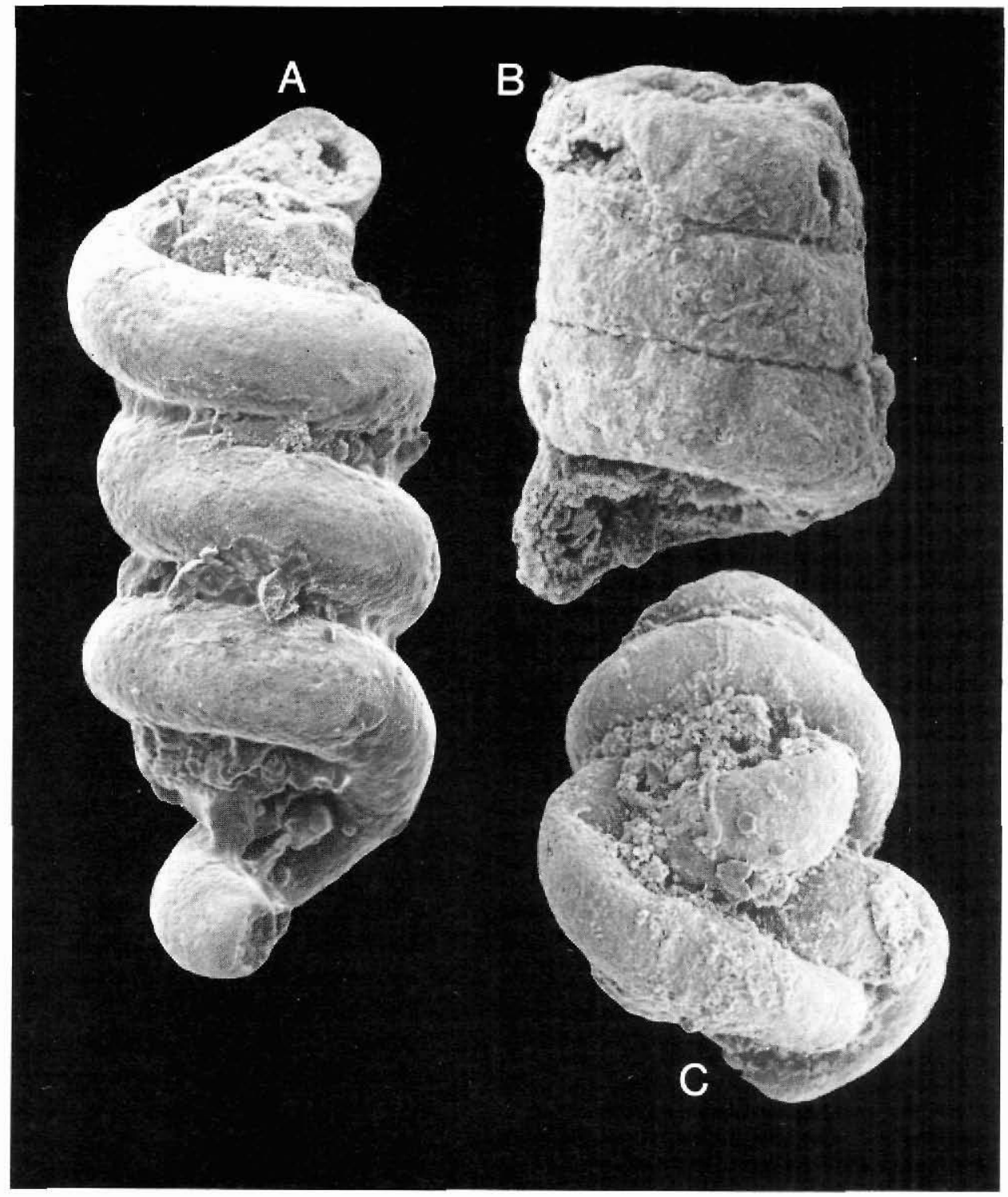

Fig. 14. A, B, Spirellus shankari (Singh \& Shukla, 1981) showing form and progressive mineralisation of the sheath. A, MGUH 17.582, open coiled example with rounded termination to the filament, $\times 200$. B, MGUH 17.583, successive mineralised coils in contact, $\times 200$. C, MGUH 17.584 , knotted termination with mineralised filament. All from GGU sample 271769, Portfjeld Formation.

mineralisation of the sheath. Whorls may be open-coiled or in contact (figs 14A, B, 15) and one of the illustrated specimens shows the rounded termination to the thread (figs 14A, 15). A degraded example shows angular folds in the coils suggesting mineralisation of the sheath (fig. 11D). 


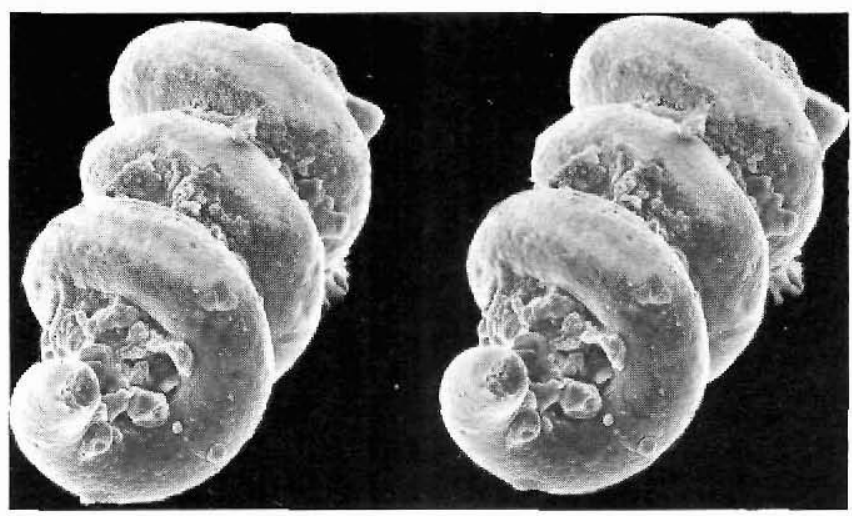

Fig. 15. Spirellus shankari (Singh \& Shukla, 1981). MGUH 17.582 from GGU sample 271769, Portfjeld Formation. Stereo pair showing rounded termination to the mineralised filament, $\times 100$.

Several knotted, mineralised threads (fig. 14C) show the same general proportions of the thread as mineralised specimens of $S$. shankari (figs $11 \mathrm{D}, 14 \mathrm{~A}, \mathrm{~B}, 15$ ) and are almost certainly the irregular termination of the otherwise helically coiled form.

Discussion. Song (1984) has discussed in some detail the question of degradation of the helix, with specific reference to Obruchevella. It would appear that diagenetic processes, such as compaction, have not played a dominating role in shortening of the helix along its axis of coiling in the material from Peary Land since the circular form of the thread in many of the helical microfossils from the Portfjeld Formation is not disturbed. Some original elasticity of the threads may have been lost on death, particularly if transverse cell walls disintegrated, causing individual whorls to come into contact. This collapse of the helix along its axis of coiling may have produced increase in the width of the helix. It is equally possible, however, that the whorls were in contact in many specimens of both Jiangispirellus and Spirellus during life and that the tightness of the helix (rate of translation along the axis of coiling) varied between individuals.

With this background, it is concluded that the first two preservational variants described above belong to the same species. The third form is also confidently assigned to $S$. shankari since its thicker threads are considered to indicate individual variation in the degree of mineralisation. The anomalous position in fig. 4A of MGUH 17.582 (figs 14A-15) relative to other Greenland specimens assigned to $S$. shankari can be explained solely by adding a layer of mineral matter about $20 \mu \mathrm{m}$ thick to the filament. Reduction of the present dimensions of the specimen by this same amount demonstrates that the thread without mineralisation would belong to $S$. shankari and not to Jiangispirellus groenlandicus.

The well preserved specimen of S.shankari illustrated in fig. 11B closely resembles the specimen figured by Jiang in Luo et al. (1982, fig. 49, pl. 15, fig. 1) from the Meishucunian Stage of China; this is the holotype of $S$. columnaris and most complete of the two specimens figured by Jiang. The dimensions of Jiang's specimen (diameter of helix $180 \mu \mathrm{m}$, width of 
filament about $30 \mu \mathrm{m}$, measured from the plate illustration) are in good agreement with the sample of specimens from North Greenland assigned to $S$. shankari. Most of the Greenland specimens have a greater helical diameter (fig. 4A) but this could result in part from the previously mentioned increase of width of the spiral following degradational compaction along the axis.

An irregularly coiled termination of the type seen in $S$. shankari (fig. 14C) is also reported in Obruchevella and its probable junior synonym Lukaschevella Vologdin, 1958 (Vologdin, 1958; Loeblich \& Tappan, 1964). Similar irregular coiling is figured in Spirellus by Singh \& Shukla (1981), Azmi (1983) and Brasier \& Singh (1987), although many of these illustrated threads appear to be degraded.

Jiang in Luo et al. (1982) referred a second new species to Spirellus, namely $S$. tarsus. Preservation of this species is too poor to permit meaningful comparison with the Greenland specimens of Spirellus.

\section{Spirellus from the Tal Formation, Indian Himalaya}

Singh \& Shukla (1981) illustrated a number of specimens under the name Glomerula shankari from the Lower Tal Formation, which they considered to be of Late Cretaceous age. Most of these are mineralised (now phosphatised) helices which can be assigned to Spirellus, as suggested by Azmi (1983) who considered the Tal phosphorites to be of late Cambrian - early Ordovician age, but to contain derived, older fossils. Discussion of the age of the Lower Tal Formation, which is now known to include strata of Late Precambrian Early Cambrian age is given by Bhatt et al. (1983); Bhatt et al. (1985); Brasier \& Singh (1987) and Kumar et al. (1987); the latter authors also figure a specimen assigned to $S$. columnaris.

The holotype of $S$. shankari was stated to represent the earlier planispiral portion of the coil but later stages in other specimens are "coiled ... in the form of a spring" (Singh \& Shukla, 1981, p. 163). Dimensions measured from illustrations and given in the accompanying text by Singh \& Shukla (1981) indicate helices from about $400-550 \mu \mathrm{m}$ in diameter and threads approaching half these values in width (fig. 4B). S. shankari is thus considerably larger than specimens of Spirellus from Greenland (fig. 4B).

Azmi (1983) placed some of the specimens of $G$. shankari illustrated by Singh \& Shukla (1981) within the synonymy of $S$. columnaris, while others were transferred to $S$. tarsus. Azmi maintained the species of Singh \& Shukla, however, to include the original holotype and two of the figured paratypes. In his discussion of $S$. shankari, which was not represented in his collections and which was cited as $S$. shankeri (a spelling also used on occasions by Brasier \& Singh, 1987), Azmi (1983, p. 397) considered the species to be characterised "by spiral coiling and then later coiled in loose planispiral way". $S$. columnaris was considered to be more perfectly spirally coiled, while $S$. tarsus was employed for "irregularly coiled tubular forms without any definite pattern of coiling" (Azmi, 1983, p. 397).

Azmi (1983, p. 396) commented that specimens he assigned to $S$. columnaris were "identical to this species", but comparison of dimensions measured from Azmi's photographic illustrations with similar parameters measured from the illustrations presented by Jiang in Luo et al. (1982) contradicts this statement. The specimen illustrated as fig. 1 on plate 9 of Azmi (1983) has a width of the now phosphatised thread of about $40 \mu \mathrm{m}$ and a diameter of the helix of about $135 \mu \mathrm{m}$. These values are similar to dimensions measured on 
the presumed holotype from Yunnan. However, specimens illustrated by Azmi (1983) on plate 9 as figs $2-5$ and 10 indicate a range in width of the thread from about $95-120 \mu \mathrm{m}$, and in the diameter of helix from $220-330 \mu \mathrm{m}$. These latter values are considerably larger than those determined for the Chinese holotype. They are, however, only half as large as specimens illustrated by Singh \& Shukla (1981, pl. 1) which Azmi included within $S$. columnaris (fig. 4B).

Brasier \& Singh (1987) placed all the Lower Tal material within $S$. shankari, employing a wider concept of the species. They noted thread diameters in the range $50-200 \mu \mathrm{m}$ and helical diameters of $200-600 \mu \mathrm{m}$. Greenland specimens lie at the periphery of this field.

\section{Progressive mineralisation of the sheath}

In fig. 4B the large specimens of Spirellus of Singh \& Shukla (1981) from the Lower Tal Formation plot far to the right of the fields for Obruchevella, Spirellus and Jiangispirellus from Greenland with most of Azmi's specimens forming a group of intermediate position between the Obruchevella and Spirellus fields and the specimens of Singh \& Shukla. Exception is provided by the specimen illustrated by Azmi (1983) as plate 9, fig. 1 which plots near the Spirellus field.

The separation can be explained largely in terms of the degree of mineralisation. As noted above for the heavily mineralised specimen of Spirellus shankari from Greenland (fig. 14A), removal of a layer of mineralisation only $20-25 \mu \mathrm{m}$ thick from around the thread serves to displace the specimen from its excentric location (AA in fig. 4A) to a position adjacent to the Spirellus field (AB in fig. 4A). The lines BA-BB and CA-CB in fig. 4B form the upper and lower limits of a field which shows the effect of uniformly increasing the thickness of the mineralised sheath in Greenland specimens of $S$. shankari. Most specimens of $S$. columnaris and $S$. tarsus of Azmi (1983) and the specimen figured by Kumar et al. (1987) are located within this field, demonstrating that the Tal specimens can be considered to be conspecific with Greenland material despite their greater dimensions.

The original material of $S$. shankari of Singh \& Shukla (1981) lies essentially above the projected Spirellus field in fig. 4B. and appears less readily united with the Greenland material on the basis of available information from Singh \& Shukla (1981). Some doubt could therefore remain as to whether or not Azmi was justified in reassigning specimens illustrated by Singh \& Shukla to either $S$. columnaris or $S$. tarsus. However, the issue has been settled by the pragmatic solution of Brasier \& Singh (1987) in re-uniting all the Tal specimens in $S$. shankari.

Acknowledgements. S. M. Awramik offered a detailed criticism of an earlier version of the manuscript; most of his suggestions for its improvement have been gratefully accepted. Stefan Bengtson also reviewed the manuscript and assisted with literature; the adopted spelling of Spirellus columnaris follows his suggestion. Anneli Uutela, Martin Brasier and Bruce Runnegar kindly helped with literature and unpublished information; many cited authors supplied copies of their publications. Darrell Long placed the fossils from the Kennedy Channel Formation of Ellesmere Island at my disposal. Niels H. Larsen and Bente Thomas provided technical and draughting support. Facilities for stereoscan photography were provided by the Laboratory for Electron Microscopy, Institute for Historical Geology and Palaeontology, University of Copenhagen. 


\section{References}

Azmi, R. J. 1983: Microfauna and age of the Lower Tal Phosphorite of Mussoorie Syncline, Gharwal Lesser Himalaya, India. Himalayan Geology 11, 373-409.

Awramik. S. M., McMenamin, D. S., Yin Chongyu, Zhao Ziqiang, Ding Qixiu \& Zhang Shusen 1985: Prokaryotic and eukaryotic microfossils from a Proterozoic/Phanerozoic transition in China. Nature 315, 655-658.

Bhatt, D. K., Mamgain, V. D., Misra, R. S. \& Srivastava, J. P. 1983: Shelly microfossils of Tommotian age (Lower Cambrian) from the chert-phosphorite member of Lower Tal Formation, Maldeota, Dehra Dun, district, Uttar Pradesh. Geophytology 13, 116-123.

Bhatt, D. K., Mamgain, V. D. \& Misra, R. S. 1985: Small shelly fossils of Early Cambrian (Tommotian) age from Chert-phosphorite Member, Tal Formation, Mussoorie Syncline, Lesser Himalaya, India and their chronostratigraphic evaluation. J. Palaeont. Soc. India 30, 92-102.

Blaker, M. R. 1988: A new genus of nevadiid trilobite from the Buen Formation (Early Cambrian) of Peary Land, central North Greenland. Rapp. Grønlands geol. Unders. 137 (this report).

Brasier, M. D. 1984: Microfossils and small shelly fossils from the Lower Cambrian Hyolithes Limestone at Nuneaton, English Midlands. Geol. Mag. 121, 229-253.

Brasier, M. D. \& Singh, P. 1987: Microfossils and Precambrian-Cambrian boundary stratigraphy at Maldeota, Lesser Himalaya. Geol. Mag. 124, 323-345.

Bykova, E. V. 1961: [Caradoc Foraminifera from eastern Kazhakstan]. Inst. Geol. Akad. Nauk Kazhak. SSR, Alma Ata: Izd. AN Kazh. SSR, 120 pp. [in Russian].

Chuvashov, B. I., Yuferev, O. V. \& Luchinina, V. A. 1985: [Middle and Upper Devonian algae of western Siberia and the Urals]. Trudy Inst. Geol. Geofiz. Akad. Nauk SSSR, Sibir. Otdel. 619, 72-99.

Cloud, P., Awramik, S. M., Morrison, K. \& Hadley, D. G. 1979: Earliest Phanerozoic or latest Proterozoic fossils from the Arabian Shield. Precamb. Res. 10, 73-93.

Conway Morris, S., Peel, J. S., Higgins, A. K., Soper, N. J. \& Davis, N. C. 1987: A Burgess shale-like fauna from the Lower Cambrian of North Greenland. Nature 326, 181-183.

Cowie, J. W. 1985: Continuing work on the Precambrian-Cambrian boundary. Episodes 8, 93-97.

Dawes, P. R. \& Peel, J. S. 1984: Biostratigraphic reconnaissance in the Lower Palaeozoic of western North Greenland. Rapp. Grønlands geol. Unders. 121, 19-51.

Demoulin, V. \& Janssen, M. P. 1981: Relationship between diameter of the filament and cell-shape in blue-green algae. Br. phycol. J. 16, 55-58.

Desikachary, T. V. 1959: Cyanophyta, 686 pp. New Delhi: Indian Council of Agricultural Research.

Flügel, E. (edit.) 1977: Fossil algae. Recent results and developments, 375 pp. Berlin, Heidelberg \& New York: Springer Verlag.

Fremy, P. 1933: Cyanophyces des côtes d'Europe. Mem. Soc. Natn Sci. Nat. Math. Cherbourg XLI, ser. 5, I, 232 pp. [reprint 1972, Amsterdam: Asher].

Friderichsen, J. D., Higgins, A. K., Hurst, J. M., Pedersen, S. S., Soper, N. J. \& Surlyk, F. 1982: Lithostratigraphic framework of the Upper Proterozoic and Lower Palaeozoic deep water clastic deposits of North Greenland. Rapp. Grønlands geol. Unders. 107, 19 pp.

Higgins, A. K., Ineson, J. R., Peel, J. S., Surlyk, F. \& Sønderholm, M. In press: The Franklinian basin in North Greenland. In Trettin, H. P. (edit.) The Innuitian region. The Geology of North America vol. E. Ontario: Geol. Surv. Canada.

Hurst, J. M. \& Surlyk, F. 1983: Initiation, evolution, and destruction of an early Paleozoic carbonate shelf, eastern North Greenland. J. Geol. 91, 671-691.

Jepsen, H. F. 1971: The Precambrian, Eocambrian and early Palaeozoic stratigraphy of the Jørgen Brønlund Fjord area, Peary Land, North Greenland. Bull. Grønlands geol. Unders. 96, 42 pp.

Kumar, G., Bhatt, D. K. \& Raina, B. K. 1987: Skeletal microfauna of Meishucunian and Qiongzhusian (Precambrian-Cambrian boundary) age from the Ganga Valley, Lesser Himalaya, India. Geol. Mag. 124, 167-171. 
Loeblich, A. R. \& Tappan, H. 1964: Sarcodina chiefly 'Thecamoebians' and Foraminiferida. In Moore, R. C. (edit.) Treatise on Invertebrate Paleontology, Part C Protista 2, 900 pp. Lawrence, Kansas: Geol. Soc. Amer. Kansas Univ. Press.

Luchinina, V. A. 1975: [Paleoalgological characteristics of the Early Cambrian of the Siberian Platform]. Trudy Inst. Geol. Geofiz. Akad. Nauk SSSR Sibir. Otdel. 216, 99 pp. [in Russian].

Luchinina, V. A. \& Voronova, L. G. 1983: [Carbonate algae] In [Lower Cambrian Stage Subdivision of Siberia. Atlas of Fossils]. Trudy Inst. Geol. Geofiz. Akad. Nauk SSSR 558, 216 pp. [in Russian].

Luo Huilin, Jiang Zhiwen, Wu Xiche, Song Xueliang, Ouyang Lin et al. 1982: [The Sinian-Cambrian boundary in eastern Yunnan, China], 265 pp. Yunnan: People's Publ. House [in Chinese].

Luo Huilin, Jiang Zhiwen, Wu Xiche, Song, Xueliang, Ouyang Lin, Xing Yusheng, Liu Guizhi, Zhang Shishan \& Tao Yonghe 1984: Sinian-Cambrian boundary stratotype section at Meishucun, Jinning, Yunnan, China, 154 pp. Yunnan: People's Publ. House [in Chinese and English].

O'Connor, B. 1979: The Portfjeld Formation (?Early Cambrian) of eastern North Greenland. Rapp. Grønlands geol. Unders. 88, 23-28.

Palmer, A. R. \& Peel, J. S. 1979: New Cambrian faunas from Peary Land, eastern North Greenland. Rapp. Grønlands geol. Unders. 91, 29-36.

Pedersen, K. R. 1970: Late Precambrian microfossils from Peary Land. Rapp. Grønlands geol. Unders. 28, 16-17.

Pedersen, K. R. 1976: Fossil floras of Greenland. In Escher, A. E. \& Watt, W. S. (edit.) Geology of Greenland, 519-535. Copenhagen: Geol. Surv. Greenland.

Peel, J. S. 1980: Early Cambrian microfossils from the Portfjeld Formation, Peary Land, eastern North Greenland. Rapp. Grønlands geol. Unders. 100, 15-17.

Peel, J. S. 1982: The Lower Paleozoic of Greenland. Mem. Can. Soc. Petrol. Geol. 8, 309-330.

Pentecost, A. \& Riding, R. 1986: Calcification in cyanobacteria. In Leadbeater, B. S. C. \& Riding, R. (edit.) Biomineralisation in lower plants and animals. Spec. Vol. Systematics Assoc. 30, 73-90.

Pratt, B. R. 1984: Epiphyton and Renalcis - diagenetic microfossils from calcification of coccoid blue-green algae. J. sedim. Petrol. 54, 948-971.

Pyatiletov, V. G., Luchinina, V. A., Shenfil', V. Yu. \& Yakschin, M. S. 1981: [New data on Precambrian fossil algae of Siberia]. Dokl. Akad. Nauk SSSR 261, 982-984 [in Russian; published in English in 1983 in Doklady Earth Sci. Sect. 261, 209-211].

Reitlinger, E. A. 1948: [Cambrian Foraminifera of Yakutia]. Byul. Moskovsk. obscest. ispytat. prirod. n.s. 53, Geol. Otdel. 23(2), 77-81 [in Russian].

Reitlinger, E. A. 1959: [Atlas of microscopic organic remains and problematica from ancient rocks of Siberia]. Trudy Inst. Geal. Akad. Nauk SSSR 25, 62 pp. [in Russian].

Reitlinger, E. A. 1960: [Microscopic organic remains and problematica in ancient rocks of the southern part of the Siberian Platform]. Proc. Int. Geol. Congr. Moscow 21, 1-62 [in Russian].

Riding, R. 1977: Calcified Plectonema (blue-green algae), a recent example of Girvanella from Aldabra Atoll. Palaeontology 20, 33-46.

Riding, R. \& Voronova, L. 1984: Assemblages of calcareous algae near the Precambrian/Cambrian boundary in Siberia and Mongolia. Geol. Mag. 121, 205-210.

Riding, R. \& Voronova, L. 1985: Morphological groups and series in Cambrian calcareous algae. In Toomey, D. F. \& Nitecki, M. H. (edit.) Paleoalgology: contemporary research and applications, 56-78. Berlin and Heidelberg: Springer-Verlag.

Schallreuter, R. 1977: Eine neue fragliche kalkschalige Foraminifere aus einem mittelordovizischen Geschiebe Norddeutschlands. Paläont. Zeitschr. 51, 227-233.

Schopf, J. W. 1968: Microflora of the Bitter Springs Formation, late Precambrian, central Australia. J. Paleont. 42, 651-688.

Schopf, J. W. \& Blacic, J. M. 1971: New microorganisms from the Bitter Springs Formation (late Precambrian) of the north-central Amadeus Basin, Australia. J. Paleont. 45, 925-960.

Schroeder, J. H. 1972: Calcified filaments of an endolithic alga in Recent Bermuda reefs. Neues $J b$. Geol. Paläont. Mh. 1972(1), 16-33. 
Shenfil', V. Yu. 1980: [Obruchevella representatives in the Riphean of the Yenisey Ridge Region]. Dokl. Akad. Nauk SSSR 254, 993-994 [in Russian; published in English in 1982 Doklady Earth Sci. Sect. 254, 247-249].

Singh, P. \& Shukla, S. D. 1981: Fossils from the Lower Tal: their age and its bearing on the stratigraphy of Lesser Himalaya. Geosci. J. 2, 157-176.

Song Xueliang 1984: Obruchevella from the early Cambrian Meishucun Stage of the Meishucun section, Jinning, Yunnan, China. Geol. Mag. 121, 179-183.

Surlyk, F. \& Ineson J. R. 1987: Aspects of Franklinian shelf, slope and trough evolution and stratigraphy in North Greenland. Rapp. Grønlands geol. Unders. 133, 59-63.

Tynni, R. \& Donner, J. 1980: A microfossil and sedimentation study of the Late Precambrian formation of Hailuoto, Finland. Bull. geol. Surv. Finland 311, 27 pp.

Vologdin, A. G. 1958: [The Lower Cambrian Foraminifera of Tuva]. Dokl. Akad. Nauk SSSR 120, 405-408 [in Russian].

Voronova, L. G. 1976: [Calcareous algae of the Precambrian-Cambrian boundary deposits of the Siberian Platform]. In Voronova, L. G. \& Radionova, E. P. [Paleozoic Algae and Microphytolites]. Trudy Geol. Inst. Akad. Nauk SSSR 294, 219 pp. [in Russian].

Wray, J. L. 1977: Calcareous algae. Developments in Palaeontology and Stratigraphy 4, 185 pp. Amsterdam, Oxford, New York: Elsevier.

Yakschin, M. S. \& Luchinina, V. A. 1981: [New materials of fossil alga Family Oscillatoriaceae (Kirchn.) Elenkin]. Trudy Inst. Geol. Geofiz. Akad. Nauk SSSR Sibir. Otdel. 475, 28-34 [in Russian]. Zhang Zhong-ying 1984: [On the occurrence of Obruchevella from the Toushantou Formation (Late Sinian) of western Hubei and its significance]. Acta Palaeont. Sin. 23, 447-451 [in Chinese with English summary]. 